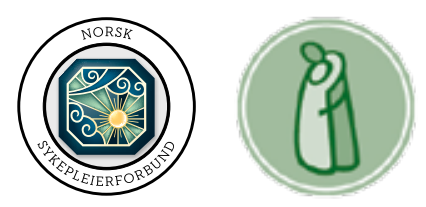

\title{
Geriatrisk sykepleie
}

NR. 3-2014 • ÅRGANG 6

NSFS FAGGRUPPE FOR SYKEPLEIERE I GERIATRI OG DEMENS

Samhandling:

V/etjve

b) Jukesse

trenge?

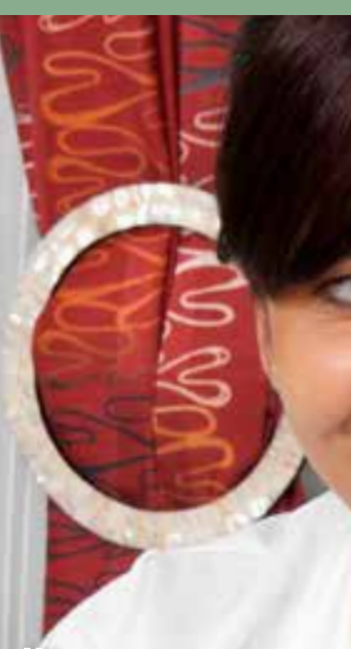




\section{Landsstyret NSF FGD 2014 - 2016}

Leder:

Tor Engevik

Storhammeren 5, 5145 Fyllingsdalen

Mobil: 90546228

e-post: tor.engevik@hotmail.no

Nestleder og ansvarlig for lokalgruppene:

Hilde Fryberg Eilertsen

Vikveien 21, 9022 Krokelvdalen

Mobil: 90104323

e-post: hildefryeil@hotmail.com

Redaktør:

Wivi-Ann Tingvoll

Hagebakken 11, 8500 Narvik

Mobil: 97539555

e-post:vat@hin.no

Økonomiansvarlig:

Marianne Kumlin

Sørlie, 2134 Austvatn

Mobil: 91594685

e-post: marianne@kumlin.biz

Konferanseansvarlig, sekretær og medlem i stipendutvalget:

Bjørg Thomassen

Landmark. 5. Bera terasse $7 \mathrm{C}$

3026 Drammen

Mobil: 47614390

e-post: bjorg.landmark@drmk.no

1. varamedlem:

Bente Skauge

Lundsvei 2B, 1710 Sarpsborg

Mobil: 91601212

e-post: besk@hotmail.no

\section{Styremedlem:}

Ranveig Lie

Mobil: 4149971

e-post: ranveig6@online.no/

ranveig.lie@ullensaker.kommune.no

\section{LOKALGRUPPELEDERE}

\section{Lokalgruppen i Agder-fylkene:}

Styret etterlyser interesserte med-

lemmer i Agder-fylkene som kan være

behjelpelig med å få lokalgruppen opp å gå igjen.

\section{Lokalgruppeleder i Hordaland: \\ Terje Årsvoll Olsen \\ Mobil: 97692620 \\ e-post: tao@broadpark.no}

\section{Lokalgruppeleder i Oppland:}

Kari-Ågot Kaltenborn Taralrud

Mobil: 91646961

epost:k.taralrud@hotmail.com

Lokalgruppelederi Oslo/Akershus:

Christine Jærv Ekrheim

Mobil: 95801093

e-post: christineekrheim@hotmail.com

\section{Lokalgruppeleder i Rogaland:}

Kari Kristin Bergersen Stærk

Telefon: 98694436

e-post:kari.kristin.sterk@stavanger-kommune.no

Lokalgruppeleder i Telemark:

Sylvi Pedersen

Mobil: 92081842

e-post:sy-ped@online.no

Lokalgruppeleder i Troms:

Hilde Fryberg Eilertsen

(se landsstyret)

Lokalgruppeleder i Vestfold:

Veslemøy Bakke

Mobil: 91863933

e-post: vesbakke@gmail.com

Lokalgruppeleder i Buskerud:

Heidi Hobbelstad

Mobil: 99704951

e-post: heho7412@hotmail.com
Lokalgruppeleder i Trøndelag:

Kari Merete Lian

Mobil: 41300912

e-post: kari_merete4@hotmail.com

Lokalgruppeleder Østfold:

Håkon Johansen

Mobil: 90850670

e-post: haaj4@online.no

\section{KONTAKTPERSONER}

Kontaktperson i Møre og Romsdal:

Liv Inger Korsnes Nilsen

Mobil: 90067142

e-post: linilse@online.no

\section{Kontaktperson i Finnmark:}

Solfrid Nilsen Lund

Telefon: 78431861

Mobil: 99646478

e-post: so-ni-lu@online.no

Kontaktperson i Hedmark:

Styret etterlyser interessert medlem $\mathrm{i}$ Hedmark som kan være kontaktperson.

Kontaktperson i Nordland:

Kirsten Willumsen

Telefon: 75554132 Mobil: 91122415

e-post:kirsten.willumsen@bodo.

kommune.no

Kontaktperson i Sogn og Fjordane: Styret etterlyser interessert medlem i Sogn og Fjordane som kan være kontaktperson. 
LEDER:

Tor Engevik

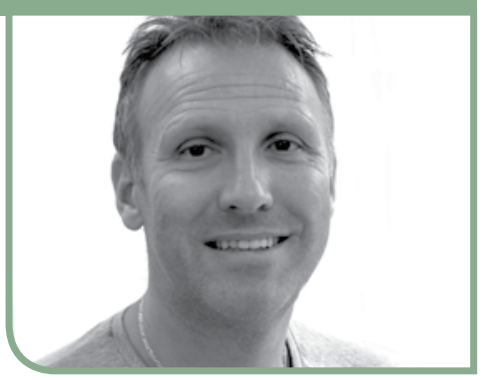

\section{Livslang trening}

Det er med stor ydmykhet jeg trer inn i rollen som konstituert leder i faggruppen for geriatri og demens etter avtroppende leder Cecilie Olsen, som sammen med resten av styret har bygget opp en veldrevet og kunnskapsrik faggruppe. Når jeg nå skal skrive min aller første leder, er jeg derfor glad for at temaet skal være «folkehelse», som er et fagområde jeg både personlig og profesjonelt er opptatt av. Trening er en viktig del av min hverdag. Daglig tilbringer jeg tid i et treningsmiljø der medlemmene er i alderen 16 til 81 år.

Våre folkevalgte er selvsagt også opptatt av folkehelse. I regjeringens folkehelsemelding som i disse dager er under utarbeiding, er aktive eldre et av fokusområdene. Mange av landets sykehjem satser på aktivitet for sine beboere, og på mange sykehjemsavdelinger har det siden 2012 pågått et sykkelprosjekt. På en stødig, stasjonær og godt tilpasset sykkel kan den eldre beboeren «tråkke» seg gjennom kjente og kjære gater som åpenbarer seg på en stor tv-skjerm etterhvert som de sykler. På den måten aktiviseres både kropp og hjerne. Rapporter fra blant andre pilotsykehjemmene konkluderer med at sykkeltiltaket har gitt positiv effekt på flere områder. Det reduser faren for falltendens, fører til raskere restituering etter skade, øker matlyst, reduserer overvekt og gir bedre søvnkvalitet.

I et folkehelseperspektiv er forebygging helt avgjørende. Og det er med trening og fysisk aktivitet som med all annen forebygging; jo tidligere du kommer i gang, jo større gevinst făr du. De som starter med trening i ung alder, vil ha en fordel av det som varer livet ut. Det er likevel helt sentralt å signalisere at det aldri er for sent å begynne. Ifølge NSFs politiske plattform for folkehelse fremgår det at forebyggingspotensialet er særlig stort før 75-årsalder der 3/4 i aldersgruppen definerer seg som friske. Trening har en positiv effekt for helse og livskvalitet også etter 75-årsalder. En av mine treningskamerater er Bjørn på 81 år. Etter en times trening med meg, går Bjørn annenhver onsdag videre for å få med seg ukens forelesning på senioruniversitetet, på biblioteket der han bor. Det er godt å få brukt både «toppen og kroppen» er hans motto. Aktivitet gir livsglede, og Bjørn er et levende eksempel på akkurat det. I tillegg til å være fysisk sprek er Bjørn et oppkomme av morsomme historier fra et langt levd liv. Humor skal heller ikke undervurderes som livsforlengende faktor.

Det er ikke alltid så mye som skal til, men trening er ferskvare, og det er den daglige aktiviteten som er viktig i et livsløp. Det gjelder også for dem som har helseproblemer. Forskning viser blant annet at styrketrening har positiv effekt for KOLSsyke da ekstra oksygen lagres i muskelmassen, hvilket bedrer reservekapasiteten, som igjen bidrar til økt livskvalitet for den syke. Diabetes type 2 er et annet eksempel på en sykdom der en viktig del av behandlingen er jevn aktivitet sammen med et sunt kosthold.

Men trening alene sikrer ikke folkehelsen. A kjenne seg trygg er et av menneskenes grunnleggende behov, og trygghetsfølelsen til den enkelte er betinget av ulike faktorer. I Bergen kommune får eldre innbyggere over 75 år som ikke mottar andre pleie- og omsorgstjenester, tilbud om trygghetssykepleier. Forebyggende hjemmebes $\varnothing \mathrm{k}$ fra en trygghetssykepleier, som gir informasjon og råd om helsefremmende tiltak, fører til at eldre făr opprettholdt eller styrket sitt funksjonsnivå. Antall eldre over 80 år skal øke fra 218.584 i 2007 til over 500.000 personer i 2050. Skal vi kunne møte denne «eldrebølgen» er vi helt avhengig av at flere av oss kan bo lengst mulig trygt og godt i egen bolig. Mestring av egen hverdag er en forutsetning for det.

Dessverre er det fortsatt slik at geografi har betydning for vår helse. I Oslo har levekårsundersøkelser vist at man lever lengre hvis man bor i vest enn om man har en bostedsadresse som ligger i øst. Bergen kommunen la ifølge Bergens Tidende den 9. september 2014 frem en levekårsundersøkelse som bygger på resultatene fra journalen fra helsestasjoner og skolehelsetjenesten i kommunen. Undersøkelsen viser at barn og unge i enkelte bydeler i Bergen er mindre fysisk aktive, har flere hull i tennene og har større grad av psykiske problemer enn i andre bydeler. Slik skal det ikke være, sier helsebyråd Hilde Onarheim som har bevilget mer penger til skolehelsetjenesten og helsestasjonene i Bergen. Hun trekker også frem tiltak som frisklivsentraler og økte bevilgninger til kriminalitetsforebyggende arbeid.

I hele livsløpet fra vugge til grav er sykepleiere en helsefremmende faktor. De fleste som blir født i dag blir tatt imot av en jordmor, og som barn og ungdom blir vi fulgt opp av helsesøster på helsestasjon eller i skolen. Får vi et langvarig eller midlertidig fravær av god helse, kan vi bli innlagt på sykehus, eller bli avhengig av hjelp fra hjemmesykepleien. I helseforebyggende tiltak som trygghetssykepleier, hukommelsesteam og frisklivsentraler har sykepleiere ofte en sentral rolle. I livets siste fase på sykehjem er det også sykepleiere som ivaretar den enkeltes helse. Vår nåværende og fremtidige folkehelse er derfor avhengig av tilstrekkelige, faglig dyktige og dedikerte sykepleiere.

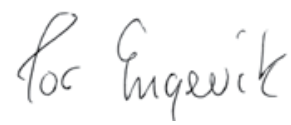

LEDER NSFS FAGGRUPPE FOR SYKEPLEIERE I GERIATRI OG DEMENS 
GERIATRISK SYKEPLEIE blir gitt ut av Norsk Sykepleierforbunds Faggruppe for sykepleiere i geriatri og demens, i samarbeid med Sykepleien.

\section{ISSN: 1891-1889}

\section{ANSVARLIG REDAKTøR \\ Wivi-Ann Tingvoll \\ Tlf. 97539555 \\ Wivi-Ann.Tingvoll@hin.no}

\section{REDAKSJONSKOMITE/FAGLIGE} MEDARBEIDERE

Jorunn Drageset, PhD, førsteaman. Universitetet i Bergen og Høgskolen i Bergen. Solveig Hauge, PhD, førsteaman., Høgskolen i Telemark og Universitetet i Oslo. Liv Wergeland Sørbye, PhD, førsteam, Diakonhjemmet høgskole. Gørill Haugan, $\mathrm{PhD}$, 1.amanuensis ved Høgskolen Sør-Trøndelag.

\section{ABONNEMENT}

Send bestilling til:

Wivi-Ann Tingvoll

Wivi-Ann.Tingvoll@hin.no

Pris: I Norge kr. 400, internasjonalt kr. 500. Institusjonsabonnement I Norge/biblioteker: kr 1000

\section{ANNONSER:}

Liv Inger Korsnes Nilsen

Tlf. 90067142

linilse@online.no

\section{HJEMMESIDE:}

Www.sykepleierforbundet.no/faggrupper/geriatri-og-demens

\section{ANSV. REDAKTøR SYKEPLEIEN} Barth Tholens

Tlf. 220433 50/40 852179

barth.tholens@sykepleien.no

\section{DESKJOURNALIST}

Johan Alvik

Tlf. 92608706

johan.alvik@sykepleien.no

\section{Astrid Svalastog}

Tlf. 97671262

astrid.svalastog@sykepleien.no

\section{LAYOUT}

Hilde Rebård Evensen

hilde.rebaard.evensen@sykepleien.no

Monica Hilsen

monica.hilsen@sykepleien.no

TRYKK Color Print A/S

\section{FORSIDEFOTO Colourbox}

\section{ANNONSERING}

Geriatrisk Sykepleie passer for annonsører som ønsker å nå sykepleiere i geriatri og demensomsorgen i alle deler av helsetjenesten. Tidsskriftet sendes alle medlemmer i faggruppen og øvrige abonnenter. Tidsskriftet har et opplag på 2000 blad. 12012 utgis Geriatrisk Sykepleie tre ganger. For nærmere informasjon om annonsering, utgivelsesplan og priser, ta kontakt med: ann.k.helgesen@hiof.no
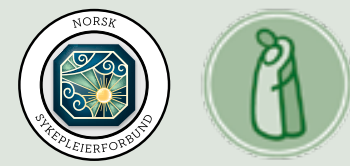

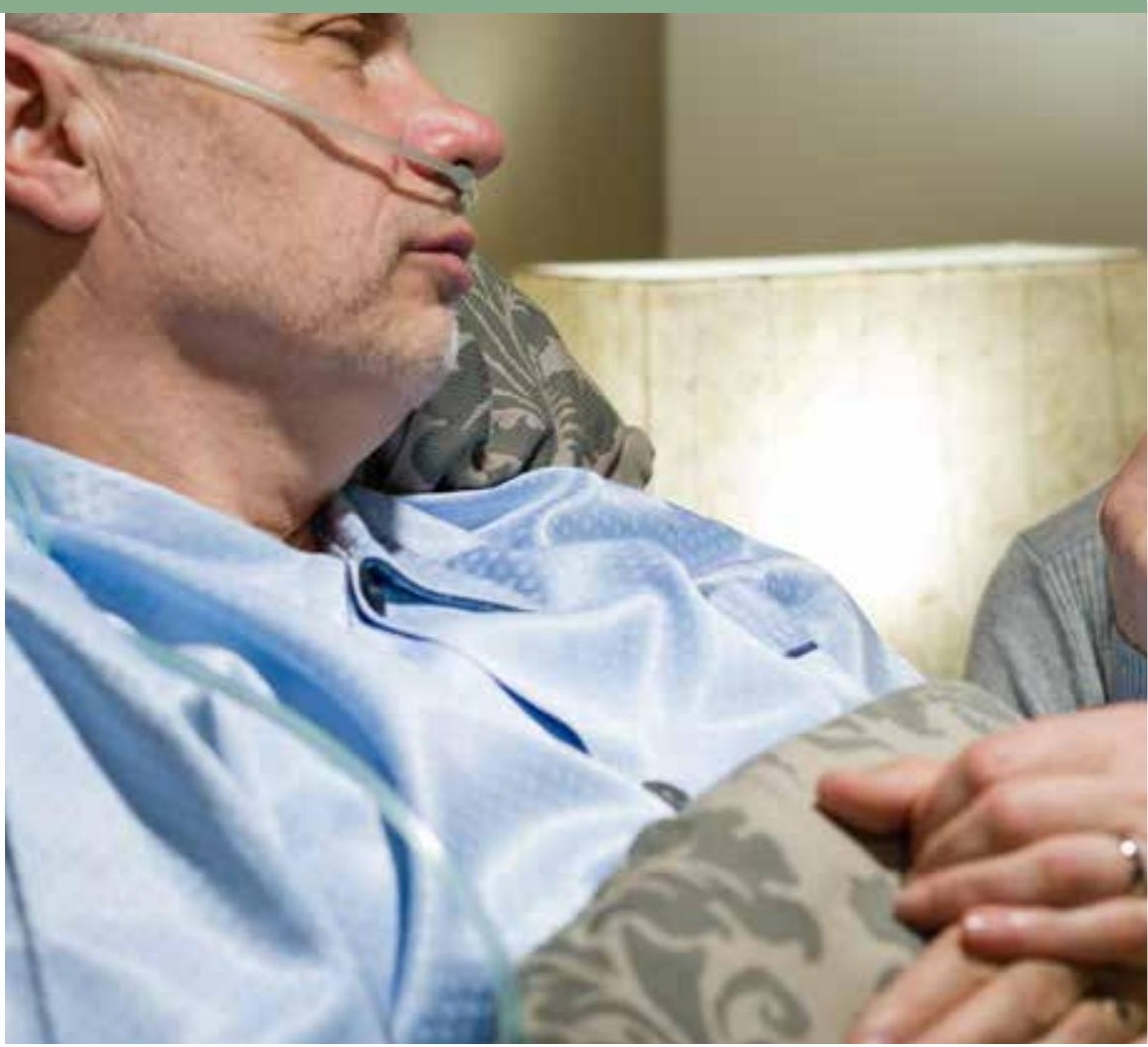

\section{«Geriatriske sykepleiere er en særs vilktig gruppe folke-

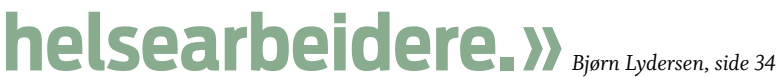

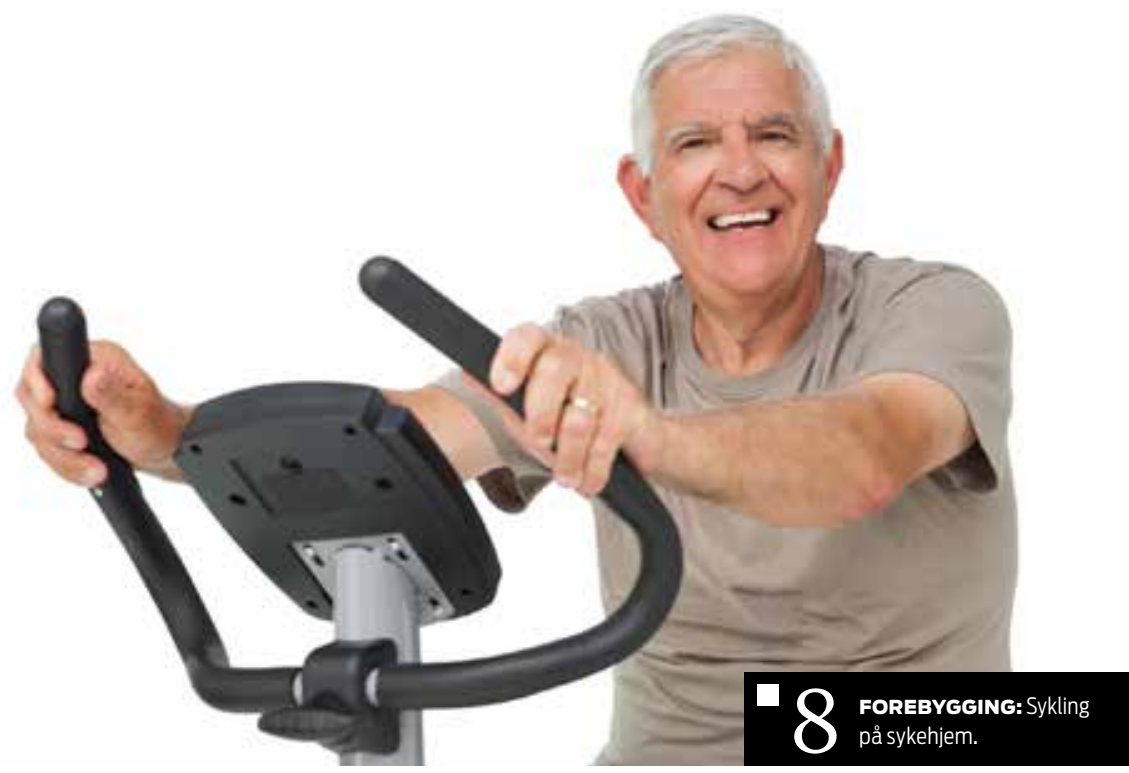




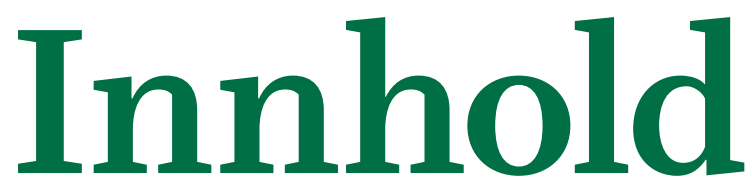

NR. 3-2014 • ÅRGANG 6

2 Landsstyret, lokale gruppeledere og kontaktpersoner

3 Leder: Tor Engevik

6 Landskonferanse i Bergen

7 Gjesteredaktør: Gørill Haugan

8 Helsebringende sykling på sykehjem

10 Behandlingsmål for eldre med diabetes

18 Hva er den gode død?

26 Samhandlingen med bestillerog utførerenheten

34 Folkehelse så lenge vi lever

\section{Vitenskapelig tidsskrift}

Geriatrisk Sykepleie er et vitenskapelig og fagfellebedømt tidsskrift som har som formål å styrke det vitenskapelige grunnlaget for geriatrisk sykepleie og sykepleie til personer med demens gjennom formidling av klinisk forskning og utvikling innen fagfeltet. Tidsskriftet er også et medlemsblad for medlemmer i Norsk Sykepleierforbunds faggruppe for sykepleiere i geriatri og demens.

Tidsskriftet publiserer vitenskapelige artikler, fagartikler, kronikker og bokanmeldelser samt reportasjer. Manuskripter sendes til ansvarlig redaktør som vedlegg til e-post. Forfatterveiledning og nærmere informasjon se nettsiden: www.sykepleierforbundet.no/faggrupper/sykepleiere-i-geriatri-og-demens 


\section{Bli med på \\ landskonferanse i Bergen}

\section{Landskonferansen 2015 blir arrangert i Bergen 19. - 20. mars.}

\section{Temaet er «Trygghet i demensomsorgen - for pasient, pårørende og sykepleier»}

«Trygghet i demensomsorgen» blir belyst gjennom en rekke interessante foredrag.

Noen av temaene er:

- Hvordan lindre smerte hos personer med demens?

- Personsentrert omsorg

- Trygghet for pårørende til personer med demens

- Demens og seksuallivet

Vi inviterer også til festmiddag på restaurant Fløyen

Arrangør er Norsk sykepleierforbunds faggruppe for sykepleiere i geriatri og demens.

Bindende påmelding kan bare gjøres elektronisk via vårt påmeldingsskjema.

Følg lenken for påmeldingen på:

www.sykepleierforbundet.no/faggrupper/geriatri-og-demens eller via følgende lenke hos vår konferansepartner http://eventus.trippus.se/nsffgd2014/tidligpamelding

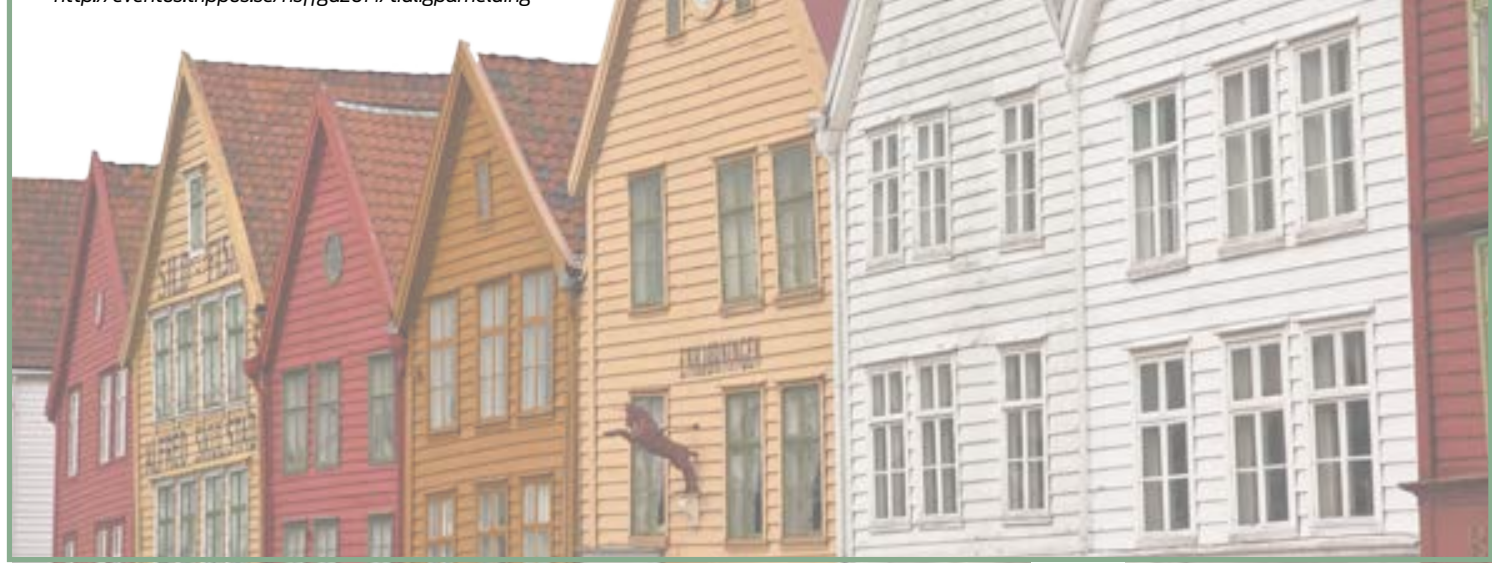

\section{NSF FGD HORDALAND ARRANGERER:}

\section{Årsmøte}

Årsmøte 12.2. kl. 20.00.

Frist for å sende inn saker er 6 uker før årsmøtet.

Kvelden begynner kl. 18.00 med et faglig fokus på «Samarbeid med pårørende til personer med demensı ved Sykepleiefaglig konsulent på Kompetansesenter for demens Bergen kommune; Trond Eirik Bergflødt.

Sted: Fyllingsdalen sykehjem

Velkommen til en matbit 17.30

Påmelding til tao@hib.no

- oppgi medlemskap og e-postadresse ved påmelding.

\section{Faglig påfyll}

NSF FGD Hordaland setter fokus på «Akutte sjukdomar hjå den geriatriske pasient.»

Foredragsholder: Sjukeheimslege Lars Riise, spes allmennmedisin.

Tid: Onsdag 5.11.2014 kl. 18.00

Sted: Toloheimen i Norheimsund - evt Rådhuset ved stor påmelding.

Pris: 200,- for medlemmer av NSF FGD og 300,- for ikke medl. NSF FGD Medlemskap i NSF FGD koster 400 kroner.

Lett bespisning frakl. 17.30

Påmelding til tao@hib.no 
GJESTEREDAKTøR: Gørill Haugan

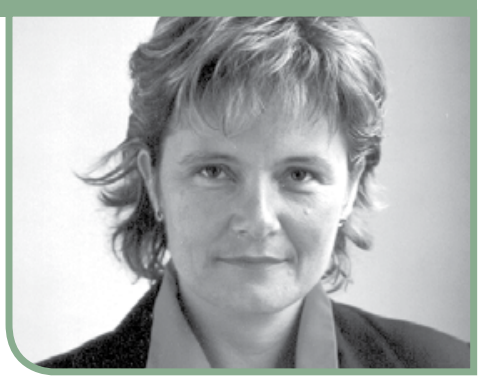

\section{Livets siste fase}

Sommeren er blitt til høst. Luften er blitt kjølig, høstregnet fyller gatene - frukter og blader faller av trærne. Vår verden møter nå høsten både i konkret og overført betydning: det er høst, og vi lever i en hurtig aldrende verden. En stor andel av verdens befolkning lever altså i sitt «livs høst». I de neste 30 årene vil antallet mennesker som er 65 år og eldre omtrent fordobles til 1.3 milliarder (1). Den største $ø$ kningen skjer blant dem som er 80 år og eldre. I 1980 var $18 \%$ av verdens befolkning over 80 år, mens dette antallet er estimert til $31 \%$ i år 2050 (2). Ergo vil det bli mange 80-, 90- og 100-åringer blant oss. En naturlig konsekvens av dette er at mange mennesker vil få ulike kroniske sykdommer. Diabetes er en hyppig forekommende kronisk sykdom blant eldre. Samtidig er denne populasjonen særlig sårbar for alvorlige komplikasjoner som bl.a. hypoglykemi. Derfor er valg av behandlingsmål hos eldre med diabetes særlig utfordrende. I sin oversiktsartikkel i denne utgaven av Geriatrisk Sykepleie drøfter Titlestad, Graue og Haugstvedt (3) individualisering av behandling for blodsukker-regulering, samt risiko for hypoglykemi hos sykehjemspasienter med diabetes. De finner at anbefalt blodsukkernivå (HbAlc) for eldre med diabetes varierer mellom 7.0 til $8.0 \%$. Samtidig fremheves individualisering av behandlingsmål som vesentlig. Den sentrale utfordringen er å finne en balanse mellom lavest mulig risiko for hypoglykemi og minst mulig ubehag og sykelighet i hverdagen for den enkelte.

Å bli gammel er likevel ikke ensbetydende med sykdom - mange gamle er friske og raske! Men - med høy alder følger ofte sykdom og funksjonstap. Som en konsekvens $\emptyset$ øer også behovet for ulike typer helse- og omsorgstjenester. I 2010 var $55 \%$ av eldre over 80 år mottakere av pleie- og omsorgstjenester (4); dette antallet vil fortsatt $ø$ ke. Kommunehelsetjenesten søker å forberede seg på denne fremtiden, og samhandlingsreformen ble innført i 2012. Videre ble en bestiller- og utførerenhet etablert i hver kommune. Nå er det dags å spørre om hvordan denne ordningen fungerer. Tingvoll, Kassah og Fredriksen (5) har studert samhandlingen mellom kommunens sykepleieledere og ansatte i bestiller- og utførerenheten. Forskerne påpeker nødvendigheten av økt kompetanse, styrket samhandling og utvikling av felles forståelse mellom fastleger, tildelingsenhet og sykepleielederne i kommunen for at ordningen bedre skal tjene pasientene og deres pårørende.

Som allerede nevnt, omtales ofte alderdommen som «livets høst»; det lakker mot vinter hvor alle de vakre sommervekstene dør. I Norge skjer de fleste dødsfall i institusjo- ner; hele $46 \%$ dør i sykehjem og $35 \%$ i sykehus, $14 \%$ dør hjemme, $4 \%$ dør andre steder mens $2 \%$ er ukjent for oss (6). Geriatrisk sykepleies høstnummer inkluderer en oversiktsartikkel om «Hva er den gode død» blant eldre mennesker. Til tross for at døden anses som en naturlig del av livet, har vi til nå lite etablert kunnskap om hva som karakteriserer den gode død for gamle mennesker. Beate André har gjort en systematisk gjennomgang av hva forskning og faglitteratur betegner som det essensielle i begrepet «den gode død» blant eldre mennesker, samt hvilke konsekvenser innholdet i begrepet kan ha for sykepleie (7). «Artikkelen viser at dødsangst er et hyppig fenomen også blant eldre døende, og at en helhetlig tilnærming med vekt på verdighet er avgjørende for en «god død» for den gamle pasienten. Omsorg ved livets slutt må derfor også involvere en beskrivelse av hvordan dødsangst kan arte seg blant gamle mennesker og hvordan vi kan bidra til å lindre denne plagen. God dokumentasjon, kommuniksajon, symptomlindring og kompetanse er avgjørende for den «gode død» også for eldre døende pasienter.»

Den røde tråden i høstnummeret av Geriatrisk Sykepleie er nettopp høsten som livets sluttfase, hvor vi modnes, eldes, blir syke og til slutt dør. Hvordan kan vi tilrettelegge pleie- og omsorgstjenestene best mulig, gi individualisert behandling til eldre med kroniske sykdommer, og hvordan kan vi til slutt bidra til en god død og verdig avslutning av et langt liv på jorden? Viktige spørsmål! God lesning!

\section{Referanser:}

1. Kinsella, Kog He W:U.S. Census Bureau, International Population Reports,P95/09-1, An Aging World: 2008, U.S. Government Printing Office, Washington, DC, 2009

2. OECD: Aging Populations: The Social Policy Implications. 1988. Paris -Washington, D.C.: OECD Publications and Information Centre

3. Titlestad I, Graue M \& Haugstvedt A: Individualisering av behandlingsmål for eldre med diabetes. Geriatrisk Sykepleie 3, 2014

4. Helsedirektoratet (2010) Samhandlingsstatistikk; IS-1958.

5. Tingvoll W-A, Kassah BL og Dreyer Fredriksen ST: Samhandling mellom sykepleieledere og ansatte i bestiller- og utførerenheten i pleie- og omsorgstjenesten. Geriatrisk Sykepleie, 3, 2014.

6. SSB 2011 03297: Dødsfall etter dødssted

7. André B: Hva er «den gode død»? Geriatrisk Sykepleie, 3, 2014

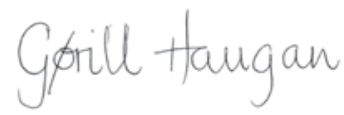

GJESTEREDAKTøR 


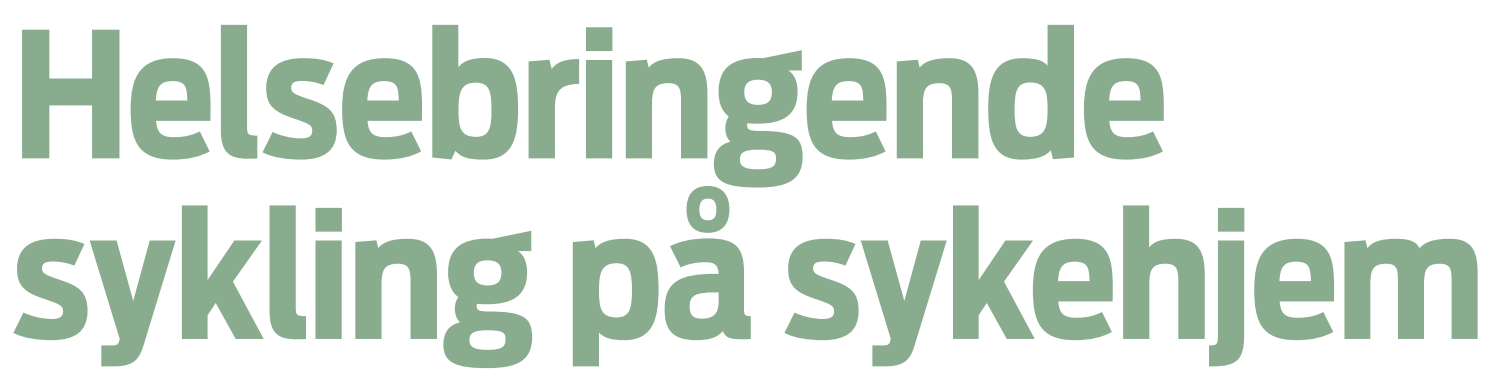

Sykling i kombinasjon med levende bilder og lyd gir sykehjemsbeboere mulighet til å «dra på sykkeltur» i kjente omgivelser. Målet er å finne ut om syklingen kan forebygge fall og skader.

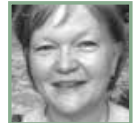

Tekst Edel Bruun Bastøe, lederNSFs faggruppe for ortopediske sykepleiere

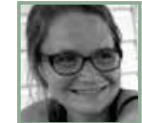

Tekst Gudrun Karlsen, nestleder

faggruppas styre og prosjektleder for prosjekt «Helsebringende sykling» all er den vanligste årsaken til at eldre skader seg i og utenfor helseinstitusjoner. Fall kan ha mange negative konsekvenser for eldre mennesker. Mellom 10 og $20 \%$ av fallene i sykehjem gir alvorlig skade. og fortsetter å øke fordi antallet eldre $ø$ ker. Én av fire av tidligere selvhjulpne mennesker blir pleiepasienter, og halvparten får redusert gangfunksjon. For eldre med hoftebrudd er dødeligheten etter ett år cirka 25 \%, og dødelighe-

\section{«Sykling kan være god rehabill- tering etter brudd.»}

NSFs faggruppe for sykepleiere i ortopedi (NFSO-NSF) ønsker å bidra til å styrke folkehelse gjennom fokus på forebyggende sykepleie. Prosjektet «Helsebringende sykling» ønsker å gjøre det mulig å redusere fall og fall med bruddskade hos sykehjemsbeboere, og samtidig styrke kompetansen rundt fallforebygging og forebyggende sykepleie. Prosjektet foregår ved Rokilde sykehjem i Kristiansund.

\section{Flere hoftebrudd}

I Norge skjer det omtrent 10000 hoftebrudd hvert år. De siste 25 årene har forekomsten av hoftebrudd økt, ten økes ytterligere, til $50 \%$, om ikke den gamle med hoftebrudd mobiliseres tilfredsstillende i etterkant av bruddbehandlingen.

Helsebringende sykling kan dermed også være en god rehabilitering etter brudd. Hoftebrudd innebærer uansett en risiko for tap av funksjon og økt avhengighet.

\section{Minimum to dager per uke}

Alle deltakerne i prosjektet, som er beboere på Rokilde Sykehjem i Kristiansund, har faste dager de skal sykle. Minimum er to dager per beboer per uke. Når på døgnet det sykles planlegges etter beboerens dagsform og personalets gjøremål i avdelingen. Prosjektet har to hovedmål: Å redusere falltendens og fall med bruddskade hos sykehjemsbeboerne, samt å styrke kompetansen rundt fallforebygging hos personalet ved sykehjemmet. Ergometersykkelen som benyttes i prosjektet har ikke eget sete. Det er viktig at den som skal sykle sitter trygt og behagelig i egen stol. Sykkelen kan derfor også benyttes av beboere med rullestol. Ergometersykkelen har elektrisk motor og mulighet for å benytte hjelpemotor slik at kroppen får bevegelse, og gjør det lettere å tråkke når beboeren ikke lenger aktivt sykler selv. Det er også mulig å velge aktiv armbevegelse ved innstilling av håndtaket. Sykkelen har et display hvor man kan gjøre innstillinger som motstand for de syklistene som trenger det. Man kan lese av hvor langt beboerne har syklet, hvor lenge treningsøkten varte, kaloriforbruk og hvor aktiv eller passiv syklingen har vært osv. 


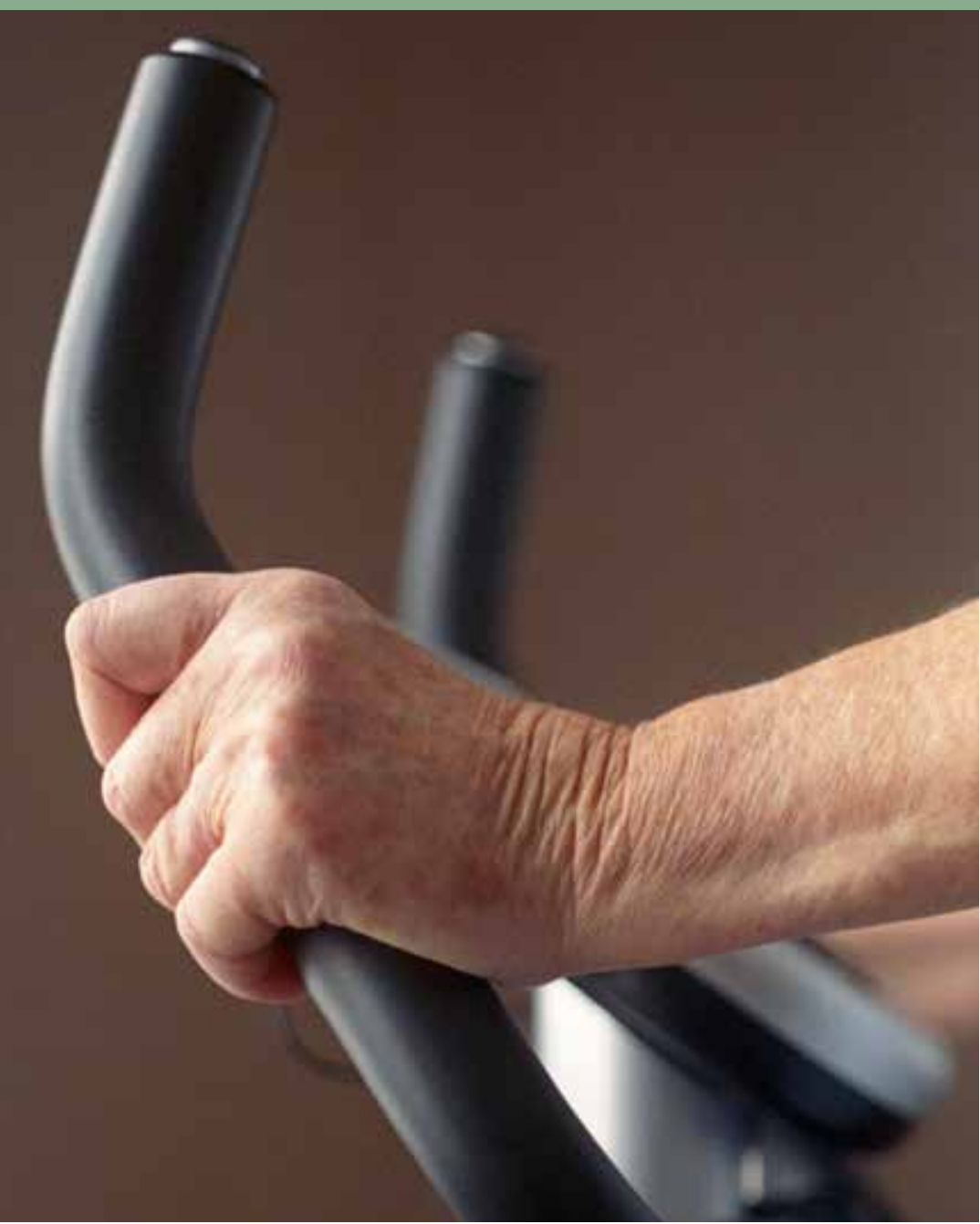

\section{Prosjekt helse- bringende sykling}

Mål

- Åredusere falltendens og fall med bruddskade hos sykehjemsbeboere.

- Styrke kompetansen rundt fallforebygging hos personalet ved sykehjemmet.

Metode

Sykling innendørs motivert av film og musikk tilpasset beboerne.

- Sammenligne antall fall og sykehusinnleggelser relatert til fall 2013/2014 med tilsvarende tall for prosjektperioden.

$\emptyset$ nskede resultater

Redusere FALL med $65 \%$.

Redusere innleggelser i sykehus med $50 \%$.

Redusere hoftebrudd med $50 \%$

Motivasjon for $ø$ kt fysisk aktivitet og forebyggende helsearbeid.

Ønskede konklusjoner

- Sykling motivert av film og musikk forebygger fall og øker motivasjonen for trening hos beboerne i sykehjem.

- Gjentakende fysisk aktivitet avhenger av sykepleiers kunnskap og motivasjon.

$\emptyset \mathrm{kt}$ appetitt, økt muskelmasse og forbedret balanse.

TRYGT: De eldre sitter trygt og behagelig i ergometersyklene som brukes i prosjektet. Illustrasjonsfoto: Scanpix/Science Photo Library.

\section{Film og musikk}

Motivasjon for trening er avgjørende. Det viktigste utgangspunktet for motivasjon og glede er filmer fra kjente gater og steder i lokalmiljøet. Å kunne sykle gjennom kjente gater, peke på steder man har vært og fortelle om opplevelser knyttet til de ulike stedene gir mange motivasjon til å sykle lengre. Syklingen i kombinasjon med film gir gevinst i form av bedre balanse, bedre ernæringsstatus, raskere rehabilitering ved skade, reduksjon i utagering/sinne, bedre søvn, økt trivsel, mindre smerter. Prosjektet håper derfor å kunne konkludere med at man vil se færre fall og fall med bruddskader hos beboerne, og altså færre innleggelser i sykehus, en styrket folkehelse og økt kunnskap om fall og forebygging av fall hos personalet.

\section{Foreløpige erfaringer}

- Mange fall, færre brudd hos sykehjemsbeboerne.

- Utfordrende å holde motivasjonen ved like hos personalet.

- Tidkrevende å motivere pasienter for gjentagende bruk.

- Økt kunnskap om fall og fallforbygging i helsetjenesten er nødvendig.

- Konseptet passer for de aller fleste eldre, men benyttes av utvalgte pasienter.

\section{《Ergometer- sykkelen har elektrisk motor „»)}

\section{Referanser:}

1. Prosjekt Helsebringende Sykling/NFSO-NSF

2. Motitech.no: http://issuu.com/motitech/docs/ motiview

3. Nhi.no: http://nhi.no/sykdommer/muskel-skjelett/ beinbrudd/larhalsbrudd-5020.html?page $=8$ 


\section{Behandlingsmål for eldre med diabetes}

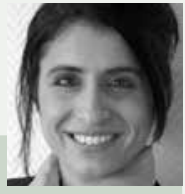

Av Irit Titlestad, sykepleier, masterstudent ved Høgskolen i Bergen. Diabetessykepleier i Askøy kommune

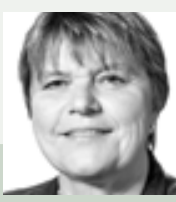

Av Marit Grave, sykepleier, master i sykepleievitenskap, dr. polit fra Institutt for samfunnsmedisinske fag, Universitetet iBergen. Professor ved $\mathrm{H} ø g s k o l e n$ i Bergen

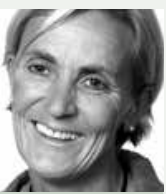

Av Anne Haugstvedt, sykepleier/helsesøster, master i sosiologi, phd fra Institutt for samfunnsmedisinske fag, Universitetet i Bergen. Førsteamanuensis ved $\mathrm{H} ø g$ skolen iBergen
Introduksjon

I følge International Diabetes Federation (IDF) er det forventet at antallet mennesker med diabetes vil $ø$ ke kraftig i hele verden i årene fremover (1). Denne økningen, og den generelle økningen i andelen eldre i befolkningen, medfører også en forventet økning av antall eldre med diabetes i sykehjem (2). Studier på sykehjem og aldershjem i USA har vist en varierende prevalens av diabetes på mellom 22 og 33 \% (3). I Norge har vi få studier som viser diabetesprevalens i sykehjem. To studier fra sykehjem på Vestlandet har vist en forekomst av diabetes på $15-17 \%(4,5)$.
Det er godt dokumentert at diabetes og diabetesrelaterte følgetilstander medfører økonomiske, sosiale og helsemessige belastninger både for den enkelte med diabetes, den nærmeste familien, samt for helsetjenesten totalt sett. Likevel er diabetes blant eldre et forholdsvis neglisjert tema i medisinske litteratur (6). Vi har begrenset kunnskap om kompleksiteten i pleie og behandling ettersom eldre og/eller individer med flere sykdommer ofte har blitt ekskludert fra studier som omhandler behandling og behandlingsmål for diabetes (2). Som en konsekvens av dette er kunnskapsgrunnlaget noe begrenset når det gjelder å

\section{Sammendrag}

Introduksjon: Valg av behandlingsmål for eldre med diabetes i sykehjem er utfordrende på grunn av pasientgruppens alders- og helserelaterte sårbarhet for alvorlige komplikasjoner som blant annet hypoglykemi.

Hensikt: Å drøfte behandlingsmål for blodsukkerregulering og risiko for hypoglykemi hos eldre med diabetes på sykehjem med bakgrunn i litteratur om gjeldende nasjonale og internasjonale kunnskapsbaserte retningslinjer og anbefalinger.

Metode: Et litteratursøk ble gjennomført for å identifisere nasjonale og internasjonale kunnskapsbaserte retningslinjer og anbefalinger for behandlingsmål for blodsukker og dets relasjon til risikoen for hypoglykemi hos eldre med diabetes. Resultater: Litteraturen viser at anbefalinger for glykosylert hemoglobin (HbAlc) for eldre med diabetes varierer mellom $7.0 \%$ og $8.5 \%$. Både nasjonale og internasjonale kunnskapsbaserte retningslinjer vektlegger individualisering av behandlingsmål. Det er mangel på konkrete anbefalinger for behandlingsmål for eldre med diabetes i Helsedirektoratets nasjonale faglige retningslinjer for diabetes. I internasjonale retningslinjer er det gitt anbefalinger som innebærer en vurdering av risiko for hypoglykemi opp mot eventuelle fordeler med en strammere blodsukkerregulering.

Konklusjon: Valg av optimalt behandlingsmål for blodsukkerregulering hos eldre med diabetes, handler om å finne en balanse mellom lavest mulig risiko for hypoglykemi og minst mulig ubehag og sykelighet som følge av hyperglykemi i hverdagen.

Nøkkelord: Diabetes, eldre, litteraturstudie.

\section{Abstract}

Introduction: Selecting treatment goals for elderly with diabetes in nursing homes is challenging due to their age and health-related vulnerability to serious complications, such as hypoglycemia.

Aim: To discuss treatment goals for blood glucose regulation and the risk of hypoglycemia among elderly with diabetes in nursing homes using national and international evidence based guidelines.

Methods: A literature search was conducted to identify national and international evidence based guidelines and recommendations for treatment goals for blood glucose and their relation to the risk of hypoglycemia among elderly with diabetes.

Results: The literature indicates that the recommended level for glycated hemoglobin (HbAlc) among elderly with diabetes varies between $7 \%$ and $8.5 \%$. In addition, both national and international evidence based guidelines emphasize the individualization of treatment goals. The Norwegian diabetes guidelines, however, lack specific treatment goals for elderly patients with diabetes. International guidelines, on the other hand, give recommendations that relate the risk of hypoglycemia to the potential benefits of tighter blood glucose regulation. Conclusion: Selecting optimal treatment goals for blood glucose regulation among elderly with diabetes is about finding a balance between the minimum risk of hypoglycemia and the minimum discomfort and morbidity as a result of hyperglycemia.

Keywords: Diabetes, elderly, literature study. 


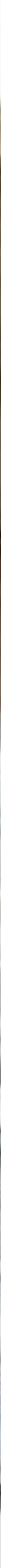

fikt behandlingsmål for eldre.

Illustrasjonsfoto: Colourbox. 
kunne utforme konkrete retningslinjer som er direkte tilpasset diabetes hos eldre, og derved også for sykehjemspasienter (7).

Et viktig mål med diabetesbehandling hos alle aldersgrupper er å oppnå tilfredsstillende blodsukkerregulering, målt ved glykosylert hemoglobin (HbAlc), samt å forebygge symptomgivende hypo- og hyperglykemi (8). HbA1c dannes når glukose binder seg til hemoglobinet ved en irreversibel reaksjon og gir uttrykk for gjennomsnittlig blodglukosenivå de siste 6-12 uker (9, s.36) (Tabell 1). Hypoglykemi er en tilstand der blodsukkernivået er for lavt, gjerne under $3.9 \mathrm{mmol} / \mathrm{l}$. Kroppen har da ikke tilstrekkelig energi til å fungere som normalt (10). Ifølge norske behandlingsretningslinjer (11) er det vanskelig å ha en entydig definisjon av hypoglykemi. De fleste vil kjenne ubehag og få symptomer når blodsukkernivået synker under omlag $3.3 \mathrm{mmol} / \mathrm{l}$, men det er individuelle forskjeller. Hypoglykemi kan sies å være en bivirkning ved noen typer blodsukkersenkende behandling. Dette gjelder insulin, sylfonylurea-tabletter og noen andre tabletter. Hypoglykemi kan gi lite spesifikke symptomer og være spesielt langvarig og alvorlig ved bruk av sulfonylurea (11). Blant brukere av insulin og sulfonylurea kan høy alder, lang varighet av diabetes, komorbiditet, polyfarmasi, tidligere episoder med hypoglykemi, underer-

\section{«Diabetes blant eldre et forholdsvis neglisjert tema.»}

næring og akutt sykdom øke faren for hypoglykemi (12). Meneilly, Knip og Tessier (13) hevder at alder er en risikofaktor for alvorlig hypoglykemi, og sammenhengen mellom alder og alvorlig hypoglykemi synes å være relatert til nedsatt glukagon- og adrenalinsekresjon som svekker symptomene på hypoglykemi. Dette hindrer dermed pasienten i å få behandlet hypoglykemien på et tidlig tidspunkt. Symptomer på hypoglykemi hos eldre kan være generell slapphet, hallusinering, aggresjon og irritabilitet, sult, skjelvinger og svette (10). Hos skrøpelige eldre kan de tradisjonelle symptomer på for lavt blodsukker være ukarakteristiske. Det eneste symptom kan eventuelt bare være tegn på en forvirringstilstand eller apati, noe som kan gjøre det vanskeligere å oppdage symptomer på hypoglykemi hos denne gruppen (10). Hypoglykemi er uønsket i alle aldersgrupper, men konsekvensene kan være mer alvorlig hos eldre.

Hensikten med denne studien var derfor å drøfte behandlingsmål for blodsukkerregulering og risiko for hypoglykemi hos eldre med diabetes på sykehjem med bakgrunn i litteratur om gjeldende nasjonale og internasjonale kunnskapsbaserte retningslinjer og anbefalinger.

\section{Metode}

Kunnskapsbaserte behandlingsretningslinjer er anbefalinger for helsepersonell som er basert på den beste tilgjengelige kunnskap, og som har til hensikt å fungere som støtte for beslutninger (14). Det ble gjennomført litteratursøk i Helsebiblioteket (MEDLINE, EMBASE, Cinahl og PubMed) for å identifisere gjeldende nasjonale og relevante internasjonale kunnskapsbaserte retningslinjer og anbefalinger for behandlingsmål for blodsukkerregulering, målt med glykosylert hemoglobin Alc (HbAlc), hos eldre med diabetes. Søkeordene som ble benyttet i alle databasene i ulike kombinasjoner var «Diabetes Mellitus», «elderly», «older, aged», «hypoglycemia», «HbA1c», «glycosylated hemoglobin», «glycemic target», "guidelines», «nursing homes» og «long term care». I søkestrategien ble det også lagt inn en begrensing om at søket skulle gjelde retningslinjer og konsensusrapporter. Søk uten denne begrensningen ble gjort for å identifisere forskningslitteratur til bruk i diskusjonen av retningslinjenes anbefalinger. Første seleksjon av publikasjoner av relevans for vår problemstilling ble utført på bakgrunn av publikasjonenes titler og abstrakt. Publikasjonene som syntes å være relevante ble lest i full tekst og vurdert nærmere. I den videre seleksjon ble det gjort en vurdering av kvalitet og relevans for norske forhold generelt og for målgruppen eldre med diabetes på sykehjem spesielt. I tillegg måtte publikasjonene omtale behandlingsmål for blodsukkerregulering hos eldre. Publikasjonene skulle enten være på engelsk eller norsk og fortrinnsvis ikke være eldre enn 5 år. I tillegg til litteratursøket ble referanselister gjennomgått for å vurdere om det kunne være relevant litteratur der som ikke var identifisert gjennom litteratursøket.

\section{Resultater}

Totalt 9 publikasjoner ble på bakgrunn av våre inklusjonskriterier inkludert i vår litteraturgjennomgang. Syv av publikasjonene beskriver diabetes behandlingsretningslinjer og 2 er konsensusrapporter rettet mot diabetes hos eldre (Tabell 2). I tillegg til de 2 norske publikasjonene (nasjonal behandlingsretningslinje for diabetes og fagprosedyre for diabetes i sykehjem) $(11,12)$ ble IDF sin retningslinje (15) som er utviklet i samarbeid med WHO, inkludert. Retningslinjen fra American Diabetes Association (ADA) (16) ble også vurdert som svært relevant for norske forhold. 


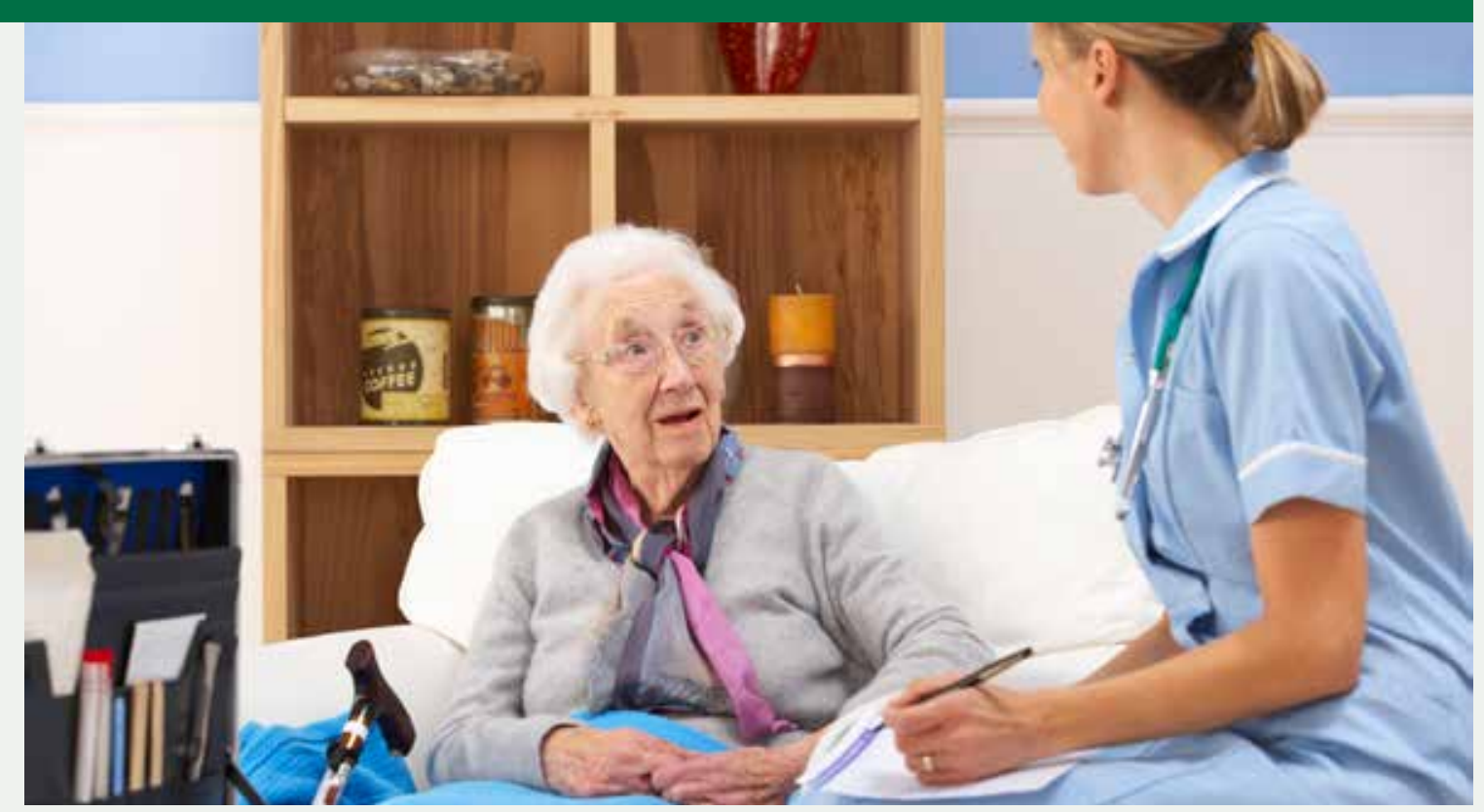

UTFORDRING: Behandlingsmål hos eldre med diabetes på sykehjem er en utfordring. Illustrasjonsfoto: Colourbox.

I begge disse retningslinjene er det gjort rede for en anerkjent metode for utviklingen av retningslinjene, noe som gir dem et kvalitetsstempel. Det samme gjaldt den inkluderte canadiske retningslinjen (13). Både USA og Canada anses å være land det er relevant for oss i Norge og sammenligne oss med. Derfor ble også retningslinjen til American Geriatrics Society (AGS) (8) og konsensusrapporten til Kirkman, Briscoe og Clark mfl. (2) inkludert. Konsensusrapporten til International Association of Gerontology and Geriatrics (IAGG), European Diabetes Working Party for Older (EDWPOP) og International Task Force of Experts in Diabetes ble utgitt i 2012 med Sinclair, Morley og Rodriguez-Mañas mfl. som forfattere og er en svært sentral publikasjon når det gjelder behandling av diabetes hos eldre i Europa (6). Vi kunne gjennom vårt søk ikke identifisere retningslinje fra det anerkjente National Institute for Health and Clinical Excellence (NICE) som omhandlet de eldste med diabetes spesielt. I tillegg til fagprosedyren «Diabetes i sykehjem» var Nettles og Reger sin «Diabetes Management in Long-term Care Facilities: A Practical Guide» (10) den eneste identifiserte publikasjonen som utelukkende var rettet mot diabetes i sykehjem.

Hva sier nasjonale og internasjonale retningslinjer om mål for HbA1c (glykemisk behandlingsmål) hos eldre med diabetes?

Den norske nasjonale faglige retningslinjen for diabetes (11) anbefaler at HbAlc generelt bør være $=7 \%$ hos voksne, men understreker viktigheten av individualisering. Retningslinjen beskriver kort at behandlingsmål for eldre må vurderes i forhold til forventet levealder og livskvalitet. Fagprosedyren
«Diabetes i sykehjem» (12), som er utviklet i Bergen kommune er mer konkret i sine anbefalinger enn den nasjonale retningslinjen, og anbefaler $\mathrm{HbAlc}$ rundt 8 \% til eldre på sykehjem. Også her vektlegges viktigheten av individualiserte behandlingsmål. Hølleland og Sunnevåg (12) hevder at det generelle glykemiske behandlingsmålet anbefalt av Helsedirektoratet (11) kan være relevant dersom pasientens forventende levetid er mer enn 5 år og det ikke er stor grad av komorbiditet og/eller høy forekomst av hypoglykemi.

International Diabetes Federation (15) sin retningslinje for eldre med type 2 diabetes anbefaler HbA1c mellom 7 og $8.5 \%$, avhengig av den enkeltes helsetilstand, funksjons- og skrøpelighetsnivå. Konsensusrapporten til IAGG, EDWPOP og International Task Force of Experts in Diabetes fra 2012, tar for seg viktige spørsmål om behandling av diabetes hos eldre $>70$ år (6). Rapporten anbefaler i utgangspunktet HbA1c mellom 7 og 7.5 for eldre. Sinclair, Morley og Rodriguez-Mañas mfl. (6) vektlegger imidlertid at det ved valg av behandlingsmål er nødvendig å vurdere pasientens individuelle kognitive og fysiske helsetilstand, og justering av målverdiene kan være nødvendig. Det pekes spesifikt på sykehjemspasienter og at behandlingen også overfor denne pasientgruppen bør tilpasses individuelt. Et av hovedmomentene til Sinclair, Morley og Rodriguez-Mañas mfl. (6) er at spørsmålet om hva som skal være behandlingsmål for blodsukkerreguleringen hos den enkelte, er et grunnleggende spørsmål som bør besvares individuelt i forhold til alle eldre med diabetes.

American Diabetes Association (ADA) (16) skriver i sin retningslinje at et rimelig glykemisk mål for 
revideres hos eldre som mister sin evne til å kjenne symptomer på hypoglykemi. De hevder videre at det å måle blodsukker regelmessig er viktig, og at man i kombinasjon med målinger må foreta systematiske observasjoner av den enkeltes reaksjoner og symptomer når hypoglykemi oppstår (10).

I konsensusrapporten til Sinclair, Morley og Rodriguez-Mañas mfl. (6) knyttes risiko for hypoglykemi til blodsukkernivå hos eldre, og det anbefales at fastende blodsukker ikke bør være lavere enn $6 \mathrm{mmol} / \mathrm{l}$. Blodsukker under $5 \mathrm{mmol} / \mathrm{l}$ gjennom dagen bør også unngås. Blodsukkernivå over $11 \mathrm{mmol} / \mathrm{l}$ bør imidlertid også unngås for å redusere symptomene og risikoen for komplikasjoner relatert til diabetes. Forfatterne fremhever at disse tallene er retningsgivende og må justeres individuelt (6).

\section{Diskusjon}

Litteraturstudien har vist at anbefalingene for HbAlc i de ulike internasjonale retningslinjene har mange likheter, men også noen ulikheter. Ulike sider ved vurdering av behandlingsmål for blodsukkerregulering, spesielt i relasjon til risiko for hypoglykemi hos eldre med diabetes på sykehjem, vil nå bli drøftet.

Den norske nasjonale retningslinjen for behandling av diabetes skiller seg fra de øvrige retningslinjer ved at de ikke angir noe spesifikt behandlingsmål for eldre (11). Den har kun en kommentar om at behandling av eldre skal vurderes i forhold til den eldre sin forventede levetid og livskvalitet. Når anbefalinger i retningslinjer er så lite konkrete kan det være vanskelig å anvende dem på en god måte. Det kan derfor reises spørsmål ved om den norske nasjonale retningslinjen er tilstrekkelige til bruk i forhold til behandling og oppfølging av eldre med diabetes. Det kan se ut som om at fagprosedyren til Hølleland og Sunnevåg (12) ble utviklet som en form for supplement til de nasjonale retningslinjer for diabetes, nettopp fordi retningslinjene manglet konkretiserte anbefalinger for eldre på sykehjem. I fagprosedyren «Diabetes i sykehjem» gis mer konkrete anbefalinger blant annet når det gjelder glykemisk behandlingsmål for eldre med diabetes på sykehjem.

De internasjonale retningslinjene om mål for blodsukkerregulering hos eldre gir både generelle anbefalinger og anbefalinger om individualisering. Sammenhengen mellom streng blodsukkerregulering og risiko for hypoglykemi løftes frem som en viktig vurdering. Men anbefalingene med tanke på fordeler av mer eller mindre streng blodsukkerregulering er ifølge Alam, Weintraub og Weinreb (17) fortsatt i stor grad beskrevet ut ifra studier med yngre populasjoner, fordi det mangler data fra kliniske studier i eldre populasjoner, og i pasientgrupper som inkluderer skrøpelige eldre. Munshi, Segal og Suhl mfl. (18) gjorde en klinisk observasjon for å evaluere hypoglykemi blant 40 eldre pasienter (> 69 år) med diabetes og HbAlc over $8 \%$ (gjennomsnittlig HbA1c $9.3 \%$ ). Hele $65 \%$ av deltakerne hadde minst en episode av hypoglykemi i løpet av en periode på 3 dager. I gjennomsnitt hadde deltakerne 4 episoder med hypoglykemi i observasjonsperioden. Forfatterne hevder at deres resultater tyder på at et mindre strengt behandlingsmål for HbAlc ikke er tilstrekkelig for å forebygge hypoglykemi blant eldre. De så også at de fleste hypoglykemiepisoder på dagtid, og nattlige episoder, ikke ble oppdaget fordi pasientene selv manglet symptomer. Forfatterne konkluderer med at deres funn viser at man må være forsiktig med å anse et mindre strengt behandlingsmål for HbAlc som det eneste og viktigste middel for forebygging av hypoglykemi og god diabetesbehandling hos eldre (18). Det påpekes at forekomsten av hypoglykemi kan ha andre årsaker enn for stram blodsukkerregulering.

I tråd med flere av retningslinjene og konsensusrapportene fremhever også Migdal, Yarandi og Smiley mfl. (19) at streng blodsukkerregulering ikke alltid er ønskelig hos sykehjemspasienter. Selv en lite alvorlig hypoglykemi kan føre til svimmelhet eller svakhet og øke sannsynligheten for fall eller brudd (20). Ifølge Migdal, Yarandi og Smiley mfl. (19) er hypoglykemi rapportert hos opp til $48 \%$ av sykehjemspasienter. Det er viktig at de gjeldende retningslinjer har konkrete anbefalinger om rutiner for blodsukkermåling og observasjoner slik at mulige årsaker til hypoglykemi blant eldre på sykehjem ikke blir oversett.

Helsetilstanden til eldre med diabetes på sykehjem er varierende og det er et stort behov for individualisering av behandlingsmål. Ved valg av behandlingsmål bør hensikten være å velge et mål som gir best mulig blodsukkerregulering og lavest mulig risiko for hypoglykemi samt færrest mulig symptomer på hyperglykemi (7). I IDF sin retningslinje for type 2 diabetes hos eldre (15) og i Kirkman, Briscoe og Clark mfl. (2) sin konsensusrapport benyttes en inndeling i 3-4 ulike kategorier ut fra helsetilstand og forventet levetid. En slik inndeling kan være en god hjelp for behandlere når behandlingsmål skal settes. Samtidig påpekes det at ikke alle pasienter er lett å plassere i en bestemt kategori og at en da selvsagt må ta hensyn til den enkelte pasients totale situasjon. Også pasientens egne preferanser må tas med i betraktning der det er relevant.

Ifølge Fravel, McDanel og Ross mfl. (21) er det 


\begin{tabular}{|l|l|l|l|l|l|l|l|l|}
\hline HbAlc, \%: & 5 & 6 & 7 & 8 & 9 & 10 & 11 & 12 \\
\hline Gjennomsnittlig blodsukker, mmol/l: & 4,5 & 6,3 & 8,2 & 10 & 11,9 & 13,7 & 15,6 & 17,4 \\
\hline
\end{tabular}

TABELL 1: Sammenheng mellom HbAlc og blodsukker (Kilde: http://www. diabetes.no/HbAlc b7C_wlbOl-.ips)

TABELL 2: Oversikt over utvalgtenasjonale og internasjonale diabetes retningslinjer og konsensusrapporter. viktig at man vurderer konsekvenser av behandling når man fastsetter behandlingsmål for blodsukkerregulering. Fravel, McDanel og Ross mfl. (21) hevder at risikoen for hypoglykemi øker når det gjennomsnittlige blodsukker reduseres. Denne risikoen øker enda mer blant eldre individer på grunn av aldersrelaterte komplikasjoner som for eksempel nedsatt nyrefunksjon og polyfarmasi. Når en avgjør intensiteten av diabetesbehandlingen, må man derfor veie risikoen for hypoglykemi opp mot mulige fordeler av en reduksjon i risiko for mikro- og makrovaskulære komplikasjoner (21). En skal også være klar over at HbAlc gir ikke indikasjon på stabiliteten i blodglukosenivået til tross for at den gir god indikasjon på hvordan blodsukkeret har vært i gjennomsnitt (17). For å sikre en god blodsukkerregulering er det derfor nødvendig med måling av både blodsukker og HbA1c.

Sammenhengen mellom lavere HbAlc og økt forekomst av hypoglykemi er imidlertid ikke entydig. I en studie av Lee, Boscardin og Cenzer mfl. (22) hadde man som hensikt å se på hypo- og hyperglykemisk utfall etter implementering av AGS anbefalinger om HbAlc $<8 \%$ hos skrøpelige eldre med diabetes. Konklusjonen var at implementering av AGS sine anbefalinger for skrøpelige eldre som bor hjemme eller på sykehjem førte til lavere HbAlc og færre episoder med hyperglykemi. I den første perioden etter implementeringen av retningslinjen var det imidlertid en økning i forekomsten av hypoglykemi som krevde sykehusbehandling, noe som ifølge forfatterne viste at implementering av retningslinje og mer fokus på måloppnåelse krevde en omlegging til mer intensiv overvåking av de eldre sitt blodsukker for å forebygge hypoglykemi (22). Hvis pasienten har lang nok forventet levetid til å ha nytte av potensielle mikrovaskulære forbedringer, kan det være hensiktsmessig med strengere mål for behandlingen. I andre tilfeller der pasienten har hatt diabetes lenge, har flere tilleggs sykdommer og ikke lang forventet levetid, kan det være urimelig og uhensiktsmessig med en streng blodsukkerregulering. Igjen ser en et behov for individualisering. Individualiserte behandlingsmål bør fastsettes på basis av tverrfaglige vurderinger hvor både sykepleier på sykehjem og tilsynslege deltar.

Den eldre sin evne til å gjenkjenne symptomer på hypoglykemi er et viktig moment som må tas med i vurderingen av behandlingsmål (13). Noen av sykehjemspasientene er plaget av ulike symptomer som tretthet og forvirringstilstand uavhengig av diabetes. Disse kan giøre det vanskelig både for helsepersonell og den eldre selv å skille mellom symptomer på hypoglykemi og andre «vanlige plager» pasientene har. Hos personer med kognitiv svikt kan det være ekstra utfordrende å oppdage symptomer på hypogly-

\begin{tabular}{|c|c|c|}
\hline Utgiver/år & Internasjonale retningslinjer & Pasientgruppe / behandlingsmål for HbAlc \\
\hline Helsedirektoratet, 2009. & $\begin{array}{l}\text { Nasjonale kliniske retningslinjer. Diabetes Forebygging, } \\
\text { diagnostikk og behandling. }\end{array}$ & $\begin{array}{l}\text { Generelle anbefalinger for personer med diabetes, } \\
\text { lite konkrete anbefalinger for eldre. }\end{array}$ \\
\hline Hølleland \& Sunnevåg, 2011. & Diabetes i sykehjem - hypoglykemi & Sykehjemspasienter \\
\hline International Diabetes Federation (IDF), 2013. & $\begin{array}{l}\text { International diabetes federation managing older people } \\
\text { with type } 2 \text { diabetes - global guideline }\end{array}$ & $\begin{array}{l}\text { Eldre populasjon som er fra relativt friske til skrøpe- } \\
\text { lige med kort forventet levetid. }\end{array}$ \\
\hline American Diabetes Association (ADA), 2013. & ADA Guidelines: Standards of Medical Care in Diabetes & $\begin{array}{l}\text { Generelle retningslinjer som også spesifikt omhand- } \\
\text { ler anbefalinger for eldre voksne (> } 65 \text { år). }\end{array}$ \\
\hline $\begin{array}{l}\text { Meneilly, Knip \& Tessier, 2013. Canadian Diabe- } \\
\text { tes Association Clinical Practice Guidelines } \\
\text { Expert Committee. }\end{array}$ & Diabetes in the elderly. & Eldre> 65år. Relevant for sykehjemspasienter. \\
\hline $\begin{array}{l}\text { Brown et al., 2003. California Healthcare Foun- } \\
\text { dation/ American Geriatrics Society (AGS) Panel } \\
\text { on Improving Care for Elders with Diabetes }\end{array}$ & $\begin{array}{l}\text { Guidelines for Improving the Care of the Older Person with } \\
\text { Diabetes Mellitus. }\end{array}$ & $\begin{array}{l}\text { Eldre populasjon (>65) som er relative friske og for } \\
\text { dem som er skrøpelige. }\end{array}$ \\
\hline Nettles og Reger, 2011. & $\begin{array}{l}\text { Diabetes Management in Long-term Care Facilities: A Practi- } \\
\text { cal Guide, 6th Edition. }\end{array}$ & Omhandler sykehjemspasienter. \\
\hline Utgiver/år & Konsensusrapporter & Pasientgruppe \\
\hline Kirkman et al., 2012. & Diabetes in Older Adults & Eldre $>65$ år. Relevant for sykehjemspasienter. \\
\hline Sinclair et al., 2012. & $\begin{array}{l}\text { International Association of Gerontology and Geriatrics } \\
\text { (IAGG), European Diabetes Working Party for Older (EDWPOP) } \\
\text { og International Task Force of Experts in Diabetes. }\end{array}$ & Eldre > 70 år. Relevant for sykehjemspasienter. \\
\hline
\end{tabular}


kemi. Meneilly, Knip og Tessier (13) hevder at kognitiv svikt er en signifikant risikofaktor for hypoglykemi. Det er derfor viktig med gode rutiner for å forebygge hypoglykemi. Det kan være hensiktsmessig med klare rutiner for måling av blodsukker og klare rutiner for daglige observasjoner i tillegg til regelmessig måling av HbAlc. For å finne balansen mellom optimalt behandlingsmål og risiko for hypoglykemi må også forhold som polyfarmasi, underernæring og aldersrelaterte komplikasjoner tas med i vurderingen $(12,21)$.

\section{Konklusjon}

Tilpasning av behandlingsmål for blodsukkerreguleringen hos eldre med diabetes på sykehjem er en utfordring for behandlere og krever grundig vurdering av den enkelte eldre sin totale helsetilstand. For å kunne gi best mulig behandling og oppfølging av denne gruppen pasienter er det viktig med gode retningslinjer. Denne litteraturgjennomgangen har vist at den norske retningslinjen for behandling

\section{Referanser:}

1. International Diabetes Federation (IDF). IDF Diabetes Atlas. Sixth edition [Internett]; 2013. Tilgjengelig fra: <http://www.idf.org/diabetesatlas/ download-book > [Hentet 2014-06-10]

2. Kirkman MS, Briscoe VJ, Clark N, Florez H, Haas LB. mfl.Diabetes in older adults. Consensus report. Diabetes Care. 2012 Desember; 35: 2650-2664.

3. Resnick HE, Heineman J, Stone R \& Shorr RI. Diabetes in US nursing homes, 2004. Diabetes Care. 2008 Februar; 31: 287-288.

4. Andreassen LM, Sandberg S, Kristensen GBB, Sølvik Uø \& Kjome RLS. Nursing home patients with diabetes: Prevalence, drug treatment and glycemic control. Diabetes Research and Clinical Practice 2014Juli; 105(1):102-9.

5. Drageset J, Nygaard HA, Eide GE, Bondevik M, Nortvedt MW. mfl. Sense of coherence as a resource in relation to health-related quality of life among mentally intact nursing home residents-a questionnaire study. Health and quality of life outcomes. 2008; 6 (1): s.85.

6. Sinclair A, Morley JE, Rodriguez-Mañas L, Paolisso G, Bayer T. mfl. Diabetes Mellitus in Older people: Position Statement on behalf of the International Association of Gerontology and Geriatrics (IAGG), the European Diabetes Working Party for Older People (EDWPOP), and the International Task Force of Experts in Diabetes. JAMDA. 2012;13:497-502

7. McCulloch DK, Munshi M, Nathan DM, Schmader KE \& Mulder JE. Treatment of type 2 diabetes mellitus in the elderly patient. Up To Date [Elektronisk artikkel]; 2013. Tilgjengelig fra: <http://www.uptodate.com/ contents/treatment-of-type-2-diabetes-mellitus-in-the-older-patient> [Hentet 2013-05-29]

8. Brown AF, Mangione CM, Saliba D, Sarkisian CA.; California Healthcare Foundation/American Geriatrics Society Panel on Improving Care for Elders with Diabetes. Guidelines for Improving the Care of the Older Person with Diabetes Mellitus. J Am Geriatr Soc. May 2003;51(5 Suppl Guidelines):s.265-280.

9. Sagen JV. Sykdomslære. I: Skafjeld A \& Grave M, red. Diabetes, forebygging, oppfølging og behandling. Oslo: Akribe forlag; 2011. s.19-73.

10. Nettles A \& Reger L. Diabetes Management in Long-Term Care Facilities: A Practical Guide 6th Edition. Minnesota State Diabetes Educators [Internett];2011. Tilgjengelig fra: <http://ltcdiabetesguide.org/downloads/ LTCguide6thEdition.pdf> [Hentet 2013-05-29]. og oppfølging av diabetes (11) mangler konkrete anbefalinger for eldre. Det finnes imidlertid internasjonale retningslinjer direkte tilpasset eldre med diabetes og eldre med diabetes på sykehjem. Noen av disse har definert glykemisk behandlingsmål (HbAlc < 8.5 \%) for skrøpelige eldre. Disse internasjonale retningslinjene ligger til grunn for anbefalingene som gis i den norske fagprosedyren «Diabetes i sykehjem.» Alle gjennomgåtte retningslinjer og konsensusrapporter påpeker imidlertid viktigheten av individualisering i forbindelse med tilpasning av behandlingsmål for eldre. Individualiseringen må ta utgangspunkt i pasientenes totale helsetilstand og pasientens egne preferanser. I store deler av litteraturen som er gjennomgått påpekes at streng blodsukkerregulering øker risiko for hypoglykemi, men det er også studier som viser at denne sammenhengen ikke er entydig. Risikoen for hypoglykemi er vist også å handle om institusjoners kompetanse og rutiner for observasjon og blodsukkermåling.

11. Helsedirektoratet. Nasjonale faglige retningslinjer - Diabetes - Forebygging, diagnostikk og behandling. Oslo; 2009.

12. Hølleland G \& Sunnevåg K. Diabetes i sykehjem. [Internett]; 2011, Nasjonalt nettverk for fagprosedyrer. Tilgjengelig fra: <http://www. helsebiblioteket.no/microsite/fagprosedyrer/fagprosedyrer/diabetes-i-sykehjem-forebygging-og-behandling-av-langtidskomplikasjoner> [Hentet 2013-08-25].

13. Meneilly GS, Knip A \& Tessier D. Clinical Practice Guidelines. Diabetes in the Elderly. Can J Diabetes. 2013; 37: 184-190.

14. Nortvedt MW, Jamtvedt G, Graverholt B, Nordheim LV \& Reinar LM. Jobb kunnskapsbasert: en arbeidsbok. 2. utg. Oslo: Akribe; 2012. $216 \mathrm{~s}$.

15. Sinclair A, Dunning T, Colagiuri S \& International Diabetes Federation (IDF) Working Group.IDF Global Guideline for Managing Older People with Type 2 Diabetes.[Internett]; 2013. Tilgjengelig fra: http://www.idf.org/ guidelines/managing-older-people-type-2-diabetes [Lest 2014-06-10]

16. American Diabetes Association (ADA). Position Statement: Standards of Medical Care in Diabetes - 2013. Diabetes Care. 2013 Januar; 36 (1 suppl):11-66.

17. Alam T, Weintraub N \& Weinreb J. What Is the Proper Use of Hemoglobin Alc Monitoring in the Elderly? JAMDA. 2006 Mars;7(3 supplement):560-564.

18. Munshi MN, Segal AR, Suhl E, Staum E, Desrochers L. mfl.Frequent Hypoglycemia Among Elderly Patients With Poor Glycemic Control. JAMA. 2011 Februar;171(4):362-364.

19. Migdal A, Yarandi SS, Smiley D \& Umpierrez GE. Update on Diabetes in the Elderly and in Nursing Home Residents. JAMDA. 2011 November; 12(9):627-632.

20.Ligthelm RJ, Kaiser M, Vora J \& Yale JF. Insulin Use in Elderly Adults: Risk of Hypoglycemia and Strategies for Care. J Am Geriatr Soc. 2012 August; 60(8):1564-1570.

21. Fravel MA, McDanel DL, Ross MB, Moores KG \& Starry MJ.Special considerations for treatment of type 2 diabetes mellitus in the elderly. Am J Health-Syst Pharm. 2011 Mars; 68 (6):500-509.

22. Lee SJ, Boscardin WJ, Cenzer IS, Huang ES, Rice-Trumble K. mfl. The Risks and Benefits of Implementing Glycemic Control Guidelines in Frail Older Adults with Diabetes Mellitus. J Am Geriatr Soc. 2011 April; 59 (4):666-672. 


\section{Introduksjon}

I Norge dør 46 prosent på sykehjem, mens 34 prosent dør på sykehus. De siste årene har det vært en tendens til at stadig flere trekker sitt siste åndedrag på sykehus, som er den mest kostbare delen av helsevesenet. Det er 14 prosent som dør hjemme, da er også akutt og uventet død inkludert (1). De aller færreste dør hjemme fordi de ønsker det. Men ser vi på døden som en naturlig del av et livsløp, er det et tankekors at den i så stor grad foregår i ulike helseinstitusjoner (2). Med få unntak er det i Norge lite systematisk kunnskap om hva som karakteriserer en god død på sykehjem og hvordan behandling, pleie og omsorg ved livets slutt foregår (3). Samtidig anses døden som en av de største utfordringene for både pasienter, pårørende og helsepersonell (4). I møte med døden er pasienter og pårørende i en sårbar situasjon, oftest forbundet med sykdom, smerte og hjelpeløshet.

For sykepleiefaget har omsorg for døende og deres pårørende lenge vært et viktig fokus (5). Hospice-bevegelsen som vokste fram i England, (6) fokuserte på den «gode død» som involverer å styrke både behandlingen og omgivelsene rundt

\section{Sammendrag}

Bakgrunn: På tross av at døden stort sett foregår på institusjoner ønsker vi i Norge å tenke at døden er en naturlig del av livet. Med få unntak er det lite systematisk kunnskap om hva som karakteriserer en god død for døende eldre og hvordan behandling, pleie og omsorg ved livets slutt foregår.

Hensikt: Denne studiens hensikt var å studere hva forskning og faglitteratur sier om begrepet og fenomenet den «gode død»), og hvilke konsekvenser dette kan få for sykepleie.

Metode: En systematisk gjennomgang av faglitteratur og forskning ble brukt som metode for og utforske hva som karakteriserer den gode død for eldre; metoden beskrives som en «integrative review».

Resultat: Denne studien fant at den helhetlige omsorgen for døende eldre pasienter må involvere en beskrivelse av hvordan dødsangst kan arte seg hos denne gruppen og hva som kan være med på å lindre den. Videre viser denne studien at det er stor enighet om at en helhetlig tilnærming med verdighet som et vesentlig element er viktig, og at konkrete tiltak som bedre dokumentasjon, kommunikasjon, symptomlindring og kompetanse er avgjørende for å kunne være istand til å tilrettelegge for den «gode død» for eldre døende pasienter. Nøkkelord: eldre døende pasienter, den «gode død», dødsangst, verdighet.

\section{What is a "good death»}

Background: In Norway, death generally takes place at health care institutions. However, despite this fact, the Norwegian health care system desires to look at death as a natural part of life. With few exceptions, systematic knowledge about what characterizes a good death and the quality of treatment and care at the end of life for dying older persons is scarce. Aims: Therefore, this study discusses what empirical research and nursing literature present to be the essential aspects of the "good death», as well as the consequences for nursing care. Methods: A systematic review of the literature and research was used. This method is described as an "integrative review" and was used to systematically provide insights concerning characteristics of the good death for older people.

Results: This study found that the holistic care of dying older patients should include a description of how death anxiety can manifest itself in this population, and describe how nurses might alleviate it. Moreover, this study revealed a general agreement on a holistic approach, emphasizing patients' perceived dignity to be essential, and that specific approaches such as improved documentation, communications, symptom relief and expertise will be important in facilitating a «good death» for older dying patients.

Keywords: elderly dying patients, the «good death», fear of death, dignity. 
PÅ SYKEHUS: De fleste eldre i Norge dør på syke-

hjem eller sykehus. Illustrasjonsfoto: NTB Scanpix.

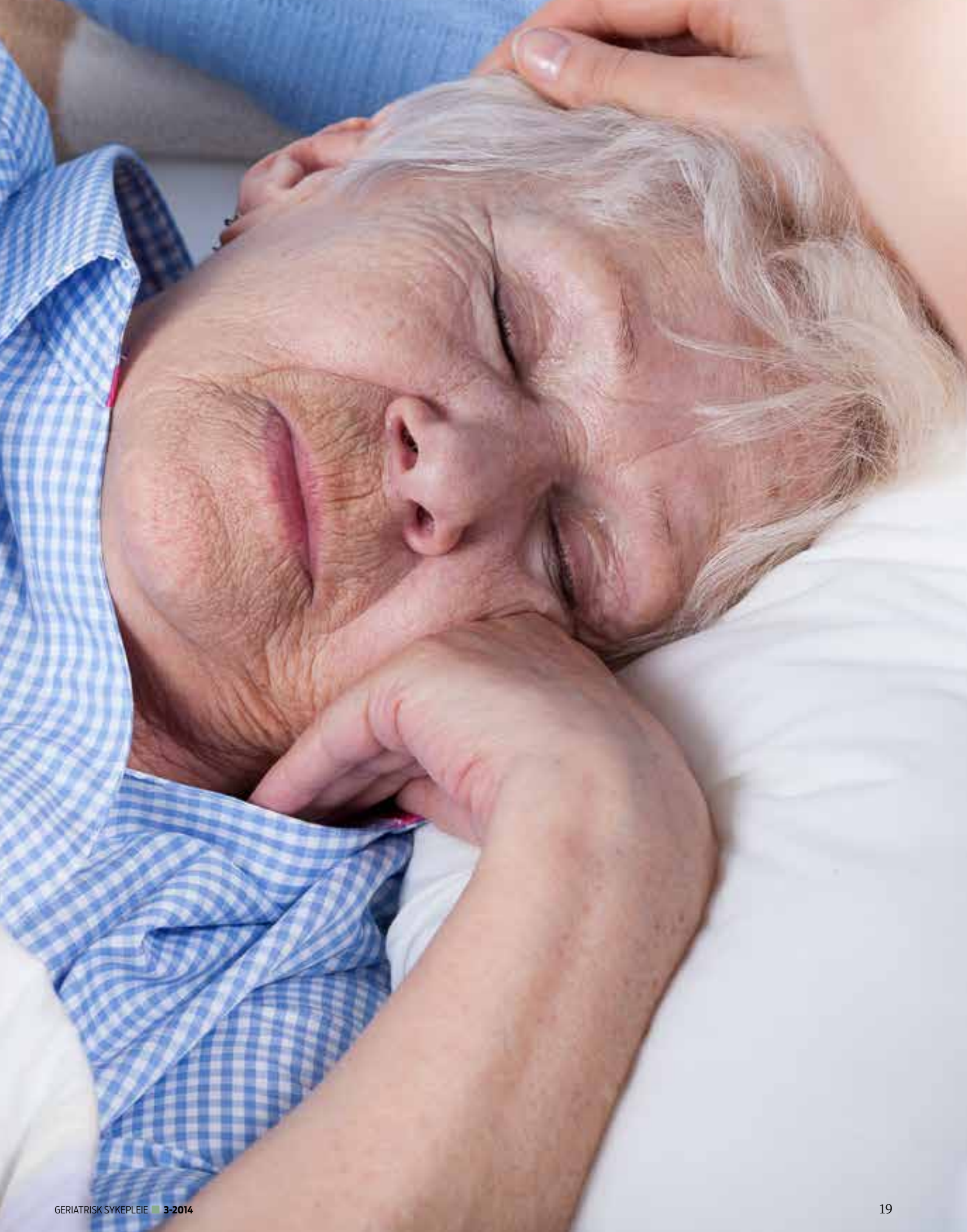


den døende. På tross av dette har fokuset i vårt samfunn vært på å unngå problemer og forhindre dårlig behandling av døende, i stedet for det positive idealet om den «gode død» (7). Vi kan derfor se for oss at vi på den ene siden registrerer økende bekymring og fremmedgjøring relatert til døden og døende, mens vi på den andre siden er vitne til en enorm teknologisk utvikling for å lindre symptomer og bedre omsorg og behandling. På grunn av økt levealder, lavere barnedødelighet, mindre familier, og økende bruk av støttende og andre medisinske intervensjoner, er det kun helsepersonell som i dag har tilstrekkelig erfaring og kjennskap til døden og døende (8). Også i Norge har døden lenge vært «profesjonalisert» ved at det er helsepersonell som er de ansvarlige når mennesker dør. Mens den helsefaglige utviklingen relatert til døden har vært fokusert på symptom- og smertelindring, har pasienter lenge også fokusert på tap av verdighet, avhengighet og tap av kontroll (8). Mange har forsøkt å definere hva som beskriver den «gode død», og «frihet fra unødvendige nød og lidelse for pasienter, familier og omsorgspersoner» (9) har vært framhevet. Dette er vel noe de fleste kan si seg enig i uavhengig av kultur, religion eller andre tradisjoner relatert til døden. Fire områder er funnet å være sentrale res-

\section{«Verdighet er knyttet opp mot kvalitet på tjenesten.»}

surser for å oppnå, en «god død» for alle pasienter: 1) forskning, 2) opplæring, 3) organisering, og 4) økonomiske rammer; alle disse vil samlet bidra til å sette standarden på omsorg for døende (8).

\section{Døden som begrep}

Per i dag finnes begrenset forskning i Norge omkring døden som begrep, og vi må derfor basere oss på hva mennesker tenker eller tror om døden. I teoriutviklingen om døden blant voksne framstilles tre konsepter av døden: 1) døden som et redskap til å oppnå mål eller belønning, som i en trussel om selvmord; 2) døden som en passasje til et nytt liv; og 3) døden som en avslutning (10). Døden kan bli sett på som en befrielse fra smerte eller også som fredelig søvn (11). Videre kan døden bli sett på som en straff, en separasjon, en gjenforening, eller noe uvirkelig (12). De her refererte artiklene (8-10) er noe gamle fra 1958, 1997 og 1998. En kan dermed undres over om holdninger og oppfatninger relatert til døden har endret seg nev- neverdig de siste decenniene, eller om oppfatninger om døden representerer en form for grunnleggende fundamental forståelse. En oversiktsartikkel fra 1979 (13) sammenlikner flere studier; funnene peker mot at alle de inkluderte studiene understøtter ideen om en sammenheng mellom menneskers psykiske tilstand og dødsangst. For eksempel finner man at mennesker som har vært eller er deprimerte opplever sterkere dødsangst enn de som ikke har vært eller er deprimerte. De finner også at variablene kjønn, alder, yrke, sosioøkonomisk status, verdiorientering, nivåer av bevissthet alle har betydning for om mennesker opplever dødsangst (13).

En artikkel om holdninger til døden i et livsløpsperspektiv beskrev fire faktorer som respondentenes holdninger til døden kunne deles inn i; 1) angst for døden, 2) tilnærmingsorientert dødsaksepasjon, 3) fluktorientert dødsaksepasjon og 4) nøytral dødsakseptasjon. De fant videre at eldre viste mindre angst for døden og mer aksept enn middelaldrende og unge respondenter. Angst for døden var negativt relatert til lykke, men positivt relatert til håpløshet, mens fluktorientert akseptasjon av døden var positivt relatert til håpløshet (14).

Dette er viktig kunnskap når vi ønsker å legge til rette for den «gode død», både med tanke på hvilke faktorer som kan påvirke grad av dødsangst og hvilke ulike perspektiver mennesker kan ha relatert til møtet med døden.

Med dette som utgangspunkt vil denne studien besvare følgende forskningsspørsmål:

Hva sier forskning og faglitteratur om begrepet den «gode død», og hvilke konsekvenser kan begrepets innhold ha for sykepleie?

\section{Metode}

En systematisk gjennomgang av faglitteratur og forskning ble brukt som metode for å komme frem til kunnskap om hva som karakteriserer den gode $\mathrm{d} ø \mathrm{~d}$ for eldre. Metoden beskrives som en «integrative review» (15) som er en spesifikk metode som oppsummerer tidligere empirisk eller teoretisk litteratur for å gi en mer fullstendig forståelse av et bestemt fenomen eller helsemessig problem (15). Integrerende review kan ha potensial til å videreutvikle vårt kunnskapsnivå i forhold til en sykepleievitenskapelig innfallsvinkel, teoriutvikling på mer generelt grunnlag, samt initiere til forskning og endring av praksis (16). Selv om en integrerende review (15) ble valgt, er retningslinjer for systematiske oversiktsstudier (17) fulgt. Studien ble gjen- 


\begin{tabular}{|l|l|l|l|}
\hline Databaser/nettsted & Søkerord & Treff & Inkluderte \\
\hline Google Scolar og ISI Web of Science & $\begin{array}{l}\text { Death and elderly patients/thoughts } \\
\text { about death and elderly/good death } \\
\text { and elderly patients/older patients } \\
\text { thoughts about death/elderly and good } \\
\text { death/concepts of death among elderly }\end{array}$ & 23 & 10 \\
\hline Sykepleien.no. & Død/eldre og død/palliasjon & 5 & 3 \\
\hline
\end{tabular}

TABELL 1: Databaser, nettsted, søkerord, treff og inkluderte.

nomført i august og september i 2014, og inkluderer både vitenskapelige publikasjoner og fagartikler innen sykepleie.

\section{Litteratursøk}

Litteratursøket ble strukturert for å identifisere artikler som beskriver døden som hovedfenomen relatert til eldre mennesker i både teoriutvikling, beskrivelser av hvordan situasjonen er og empiriske studier. Inklusjonskriteriene var: 1) døden som fenomen skulle beskrives i artiklene, og 2) utfordringer og/eller tiltak relatert til døden og eldre mennesker skulle beskrives. Studier som relaterte døden til spesifikke sykdommer, til rus, vaksiner eller sykehusinnleggelser, ble ekskludert.

To databaser og et nettsted ble gjennomsøkt for å finne relevante artikler. Søket ble begrenset til engelsk- eller norskspråklige artikler publisert fra januar 2004 til august 2014. Elektronisk søk ble foretatt i databasene Google Scolar og ISI Web of Science, og på nettstedet sykepleien.no. Flere søkeord ble anvendt: death and elderly patients; thoughts about death and elderly; good death and elderly patients; older patients thoughts about death; elderly and good death; concepts of death among elderly; død; eldre og død; palliasjon, se tabell 1. Søket resulterte i 28 artikler, hvorav 13 fylte begge inklusjonskritriene.

\section{Analyse}

De 13 artiklene som innfridde inklusjonskriteriene ble skrevet ut og studert nøye. Målet var å identifisere felles fenomener relatert til den gode død, samt utfordringer- eller tiltak relatert til møte med døden hos eldre presentert $\mathrm{i}$ artiklene. En kvalitativ tilnærming (18) er brukt i analysen for å kunne finne en felles mening og sammenheng mellom de forskjellige studiene. Fem trinn er anvendt; kategorisering av mening, kondensering av mening, strukturering av mening, tolkning av mening og til slutt å finne en form for samlet oppfattelse av hva funnene kan bety (18). Dette betyr at artiklene ble gjennomlest flere ganger, hvor en på det første trinnet finner ut hva essensen av meningen er i artikkelen. Deretter vil den eller de (det kan være flere) meningene en finner på det første trinnet forsøkes å gjøres kor-

\section{«Å bidra til en fredfull død er et mål for sykepleien.»}

tere og gjerne til setninger eller utsagn, men slik at meningsinnholdet i lys av konteksten bevares. Det neste trinnet består av at disse setningene eller utsagnene struktureres og presiseres tydeligere slik at en i det siste trinnet kan tolke de forskjellige meningene dette kan ha. De fleste setninger eller utsagn kan ha flere meninger, og det er viktig i denne prosessen at alle disse tolkningene kommer frem. I denne prosessen trekkes den samlete oppfatningen av setningene eller utsagnene ut, de blir deretter kategorisert i grupper. Selv om denne prosessen deles opp $i$ trinn, er det slik at en ofte går litt frem og tilbake i denne prosessen, dermed vil de ulike trinnene ikke alltid komme kronologisk etter hverandre (18). Alle artiklene ble studert på samme måte. Funnene presenteres i kategorier som vokste fram under analysen. For i størst mulig grad å være tro mot artikkelforfatterne, ble kategoriene presentert som hele setninger slik at konteksten kommer fram (19).

\section{Resultat}

Database- og nettstedsøket var svært forskjellig og beskrives hver for seg. Databasesøket hadde mange tusen treff, og ble sortert etter relevans med de mest relevante treffene relatert til søkerordene først. Søkene ga flere treff på de samme artiklene ved bruk av forskjellige søkeord og ved søk i forskjellige databaser/nettsted. I alt 28 artikler ble nærmere undersøkt, og av disse møtte 13 artikler alle inklusjonskriteriene. Majoriteten av de ekskluderte arti- 


\begin{tabular}{|l|l|}
\hline Verdighet & Angst for døden \\
\hline Franklin mfl (19) viser at å forstå verdighet & Depaola mfl (13) vektlegger at alderdom- \\
har viktige implikasjoner for kvalitet i syke- & men kan representere angst for økende \\
hjem. Ut fra eldre personers historier er det & nærhet til døden som en mulig tolkning. \\
viktig å bevare en følelse av verdighet. Men- & $\emptyset$ kende alder kan aktualisere eksistensielle \\
nesker trenger å bli sett og respektert for & spørsmål, som for eksempel om ens død vil \\
hvem de er. Omsorg med fokus på å fremme & bli langvarig og smertefull, hva som skjer \\
en eldre persons identitet og verdighet kre- & etter døden, og om våre liv har mening. \\
ver interesse og et ønske om å kjenne per- & Sammenhengen mellom bekymring for \\
sonen. Dette er også viktig for å gi verdig & døden og negative stereotypier knyttet til \\
omsorg ved livets slutt. Tap av kroppslige & aldringsprosessen var relatert til de eksis- \\
funksjoner og avhengighet påvirker også & tensielle spørsmålene. Eldre ønsker kanskje \\
eldre mennesker i forhold til hvordan de & psykologiskå distansere seg fra de negative \\
forholder seg ved livets slutt. De ansatte må & konsekvensene av fysisk aldring og avhen- \\
reflektere over sitt eget syn på verdighet. & gighet, samtidig kan de ved økende alder \\
Hvis verdighet forstås på en flerdimensjonal & stadig oppleve en levende påminnelse \\
måte, vil de ansatte kunne utvikle en rekke & \\
alternativer for omsorg for eldre mennesker. & \\
\hline
\end{tabular}

TABELL 2: Resultater begrepsutvikling. klene omhandlet ikke eldre, eller fokuserte på død i forbindelse med rusproblematikk eller død relatert til en spesiell sykdom, hvor sykdommen, symptomer og behandling var fokus. De 13 inkluderte artiklene ble funnet ved hjelp av systematiske søkemetoder. Følgende kategorier vokste fram under analysen; 1) begrepsutvikling, 2) forhold som påvirker en «god død» og forslag til tiltak, og 3) behandling for å oppnå den «gode død». I det videre presenteres disse kategoriene nærmere.

\section{Begrepsutvikling}

To artikler $(20,21)$ presenterte en grundig beskrivelse av begreper relatert til den «gode død». Disse var verdighet og dødsangst. Funnene i disse to artiklene er presentert i tabell 2.

Faktorer relatert eldre og den "gode død" I alt fem artikler (22-26) beskrev forskjellige faktorer relatert til hva som har betydning for eldre i møte med døden. Disse faktorene var 1) ensomhet og dødelighet hos eldre sykehjemspasienter, 2) pårørendes erfaringer når en av deres nære dør i sykehjem, 3) tanker om døden hos eldre pasienter

\section{«Dødsangst øker med økt alder..»}

med hjertesvikt, 4) angst for døden, 5) den «gode død» hos eldre med kreft og 6) den «gode død» blant terminale eldre kreftpasienter. Funnene i disse fem artiklene er presentert i tabell 3.

\section{Tiltak/omsorg i forhold til eldre døende}

I denne kategorien er det seks artikler (3, 4, 27-30) som beskrev forskjellige tiltak, omsorg eller tilrettelegging for døende eldre. Tiltakene og omsorgen for å oppnå den «gode død» var rettet mot 1) kompetanseheving i norske sykehjem, 2) respekt for pasient og pårørende, 3) dokumentasjon og kontinuitet i relasjonene, 4) god kommunikasjon med pårørende og kompetanse hos personalet, 5) tiltaksplan for døende pasienter med fokus på hva som er god praksis, 6) kvalitetssikring av omsorg til døende uavhengig av oppholdssted for pasienten og 7) reduksjon av symptomer. Tilrettelegging kan f.eks. bestå av å stille egnete rom til rådighet for pårørende, finne informasjon om tilbud til pasienter og/eller pårørende. Funnene i disse seks artiklene er presentert i tabell 4 .

\section{Diskusjon}

Forskningsspørsmålet i denne studien var rettet mot hva forskning og sykepleiefaglig litteratur dokumenterer om begrepet den «gode død» og hvilke konsekvenser begrepets innhold kan få for sykepleie. Generelt eksisterer det lite vitenskapelig og systematisk kunnskap om «den gode død», og særlig savnes studier innen populasjonen eldre. Denne studien bygger på et systematisk litteratursøk og 13 artikler som oppfylte kriteriene ble inkludert.

\section{Dødsangst}

Dødsangst er et begrep det snakkes lite om, men funnene i denne studien viser at dødsangst blir nevnt som en utfordring også blant eldre døende pasienter (21, 24-26). Det kan være naturlig å slutte at dødsangst i større grad blir sett på et som et begrep eller noe teoretisk, og ikke som et behov eller problemområde hos pasientene vi som sykepleiere kan gjennomføre tiltak i forhold til. Forskning så langt tilbake som i 1955 (11) og fram til 2003 (21) viser at dødsangst opptrer som en konstant faktor. Det er derfor viktig å være oppmerksom på og ta hensyn til fenomenet dødsangst i møte med døende. I sykepleiefaget har temaet omsorg for døende vært og er fremdeles et viktig fokusområde. Å bidra til en fredfull død er et mål for sykepleien (5). Likevel har ikke begrepet dødsangst vært fokusert i særlig grad. Hvordan vi kan møte dette problemet hos eldre døende pasienter er en vesentlig utfordring. To av de inkluderte artiklene i denne studien $(24,25)$ viser til at mange eldre vil oppleve angst for døden i større eller mindre grad, og at dette også kan øke ved 
økende alder (21). En artikkel (23) viser til at den helhetlige omsorgen i palliative enheter kan være med på å lindre dødsangst (25). Alle artiklene presentert i tabell 4 har fokus rettet mot: 1) hva vi kan gjøre relatert til eldre døende, 2) helhetlig omsorg, 3) god dokumentasjon, 4) god kommunikasjon og 5) god symptomlindring (3, 4, 27-30) uten å knytte begrepet dødsangst til disse aspektene.

\section{Verdighet}

Dette er et essensielt begrep og fenomen som flere av artiklene setter søkelyset på. Verdighet er knyttet opp mot kvalitet på tjenesten hvor dette å fremme identitet, integritet og uavhengighet hos de døende pasientene kan være med på å styrke deres verdighet (20). Flere av artiklene i tabell 3 og 4 beskriver verdighet som et viktig begrep relatert til omsorg for døende eldre $(3,24,27)$. Ser en på hva begrepet verdighet faktisk innebærer, kan en hevde at de fleste artiklene i denne studien på en eller annen måte fokuserer på eller berører verdighet og de nært relaterte begrepene nevnt ovenfor; identitet, integritet og uavhengighet. Fenomener som fortrolige forhold, emosjonell støtte, trygghet, åndelig omsorg, ærlighet, god kommunikasjon, uavhengighet, håp og glede $(3,4,22,23,25-27)$ bidrar til å styrke døende pasienters verdighet. En kan også tenke seg at bedre dokumentasjon, kompetanseheving, kvalitetssikring, symptombehandling og omsorgsmodeller (3, 4, 27-30) kan representere mer indirekte tiltak som bidrar til at den eldre pasientens verdighet blir bevart og/eller styrket.

\section{Hvordan oppnå den "gode død»}

Flere konkrete tiltak ble beskrevet i artiklene som relevante for å legge til rette for den «gode død». En rekke artikler beskriver konkrete tiltak som økt kompetanse, bedre og systematisert dokumentasjon, innføring av egne modeller for god omsorg, samt bedre kommunikasjon og symptomlindring (3, 4, 27-30). Alle disse tiltakene vil hver for seg bidra til den «gode død». Flere av artiklene som beskriver innføring av ulike omsorgsmodeller setter flere tiltak sammen til en mer helhetlig tilnærming og omsorg $(4,28,29)$. En artikkel framhever at eldre døende pasienter har behov for samme nivå av palliativ omsorg som andre alders- og pasientgrupper (30). Dette er viktig forskning, fordi til nå har kunnskapsutviklingen innen palliativ omsorg i stor grad vært basert på andre aldersgrupper enn de eldre. Når vi også vet at dødsangst øker med økt alder $(21,25)$ er det nå viktig å fokusere spesielt på denne gruppen.

\section{Konklusjon}

Denne studien finner at begrepet den «gode død» er et flerdimensjonalt begrep som både kan inneholde konkrete tiltak og tilrettelegging, så vel som en mer teoretisk begrepsavklaring i forhold til hvilke andre teoretiske begreper som kan være med å beskrive den «gode død». Begrepet dødsangst viste seg å være lite knyttet opp mot konkrete tiltak eller ulike former for tilrettelegging, men samtidig var dødsangst et fenomen som gikk igjen i mange artikler.

For å kunne tilby lindring av dødsangst, er det av stor betydning å vite hva fenomenet innebærer for denne pasientgruppen og for den enkelte pasient, samt i hvor stor grad den enkelte pasient opplever dødsangst som en utfordring eller ikke.

\begin{tabular}{|c|c|c|c|c|}
\hline $\begin{array}{l}\text { Drageset,m.fl. (22) } \\
\text { Ensomhet og dødelighet hos } \\
\text { sykehjems-pasienter }\end{array}$ & $\begin{array}{l}\text { Midtbust, m.fl. (23) } \\
\text { Pårørendes erfaringer når en av } \\
\text { de nære dør i sykehjem }\end{array}$ & $\begin{array}{l}\text { Strömberg og Jaarsma, (24) } \\
\text { Tanker om døden hos eldre } \\
\text { pasienter med hjertesvikt }\end{array}$ & $\begin{array}{l}\text { Tsai, m.fl.(25) } \\
\text { Angst for døden og den «gode } \\
\text { død» hos eldre med kreft }\end{array}$ & $\begin{array}{l}\text { Cheng, m.fl. (26) } \\
\text { Den «gode død» blant termi- } \\
\text { nale eldre kreftpasienter }\end{array}$ \\
\hline $\begin{array}{l}\text { Følelsesmessig ensomhet var } \\
\text { assosiert med økt dødelighet } \\
\text { i denne studien. Sykepleiere } \\
\text { må ta hensyn til emosjonell } \\
\text { ensomhet blant sykehjems- } \\
\text { beboere og gi særlig } \\
\text { oppmerksomhet til } \\
\text { betydningen av å tilby et } \\
\text { nært fortrolig forhold til } \\
\text { pasientene for å gi emosjonell } \\
\text { støtte. }\end{array}$ & $\begin{array}{l}\text { Pårørende opplever at døden } \\
\text { i sykehjem kan være en } \\
\text { uforutsigbar og fremmed } \\
\text { situasjon. Pårørende } \\
\text { opplevde at de alltid måtte } \\
\text { være tilgjengelige og } \\
\text { opplevde behov for trygghet. }\end{array}$ & $\begin{array}{l}\text { Tanker om døden var for noen } \\
\text { frihet fra smerte og lidelse, for } \\
\text { andre var de redd for at døden } \\
\text { kunne innebære smerter, tap } \\
\text { av uavhengighet og verdighet. } \\
\text { De var opptatt av å arrangere } \\
\text { ting etter sin død, og de } \\
\text { ønsket å leve lenger.16 \% av } \\
\text { pasientene hadde dødsangst } \\
\text { og } 4 \% \text { av dem hadde } \\
\text { dødsangst svært ofte. }\end{array}$ & $\begin{array}{l}\text { De eldre pasientene } \\
\text { opplevde høyere grad av } \\
\text { angst for døden enn den } \\
\text { yngre pasientgruppen. Den } \\
\text { helhetlige omsorgen i } \\
\text { palliative enheter kan } \\
\text { relateres til lindring av } \\
\text { dødsangst. Det er behov for } \\
\text { psykologisk og åndelig } \\
\text { omsorg for å redusere } \\
\text { dødsangst hos eldre } \\
\text { pasienter. }\end{array}$ & $\begin{array}{l}\text { Dilemmaet med det å være } \\
\text { ærlig overfor eldre dødende } \\
\text { pasienter kan kompromit- } \\
\text { tere autonomien og påvirker } \\
\text { dermed hvordan de skårer } \\
\text { relatert til den «gode død» i } \\
\text { denne studien. Det palliative } \\
\text { teamet bør legge vekt på } \\
\text { ærlighet i omsorgen for } \\
\text { dødssyke eldre pasienter. }\end{array}$ \\
\hline
\end{tabular}

TABELL 3: Faktorer relatert eldre og den «gode død». 


\begin{tabular}{|c|c|c|c|}
\hline Artikkel & Tiltak & Omsorg/pleie & Konklusjon \\
\hline Kaarbø (4) & $\begin{array}{l}\text { Undervisning og kompetanseheving for } \\
\text { personalet ved fire sykehjem i Norge. }\end{array}$ & $\begin{array}{l}\text { Bedre omsorg til alle som dør på syke- } \\
\text { hjem gjennom innføring av en } \\
\text { omsorgsmodell. }\end{array}$ & $\begin{array}{l}\text { Pårørende rapporterte bedre informa- } \\
\text { sjon og kommunikasjon etter innførin- } \\
\text { gen av modellen. }\end{array}$ \\
\hline Gjerberg og Bjørndal (3) & $\begin{array}{l}\text { God dokumentasjon, systematisk } \\
\text { observasjon, rutiner for oppfølging, god } \\
\text { smertelindring og annen symptombe- } \\
\text { handling. }\end{array}$ & $\begin{array}{l}\text { Personalets respekt for pasienten og } \\
\text { de pårørende er en grunnforutsetning } \\
\text { for god og verdig livsavslutning. }\end{array}$ & $\begin{array}{l}\text { Kontinuitet i relasjonene mellom pasi- } \\
\text { ent/pårørende og ansatte og god kom- } \\
\text { munikasjon er viktige forutsetninger. }\end{array}$ \\
\hline Steindal og Sørbye (27) & $\begin{array}{l}\text { En verdig død ved sykehjem fordrer mer } \\
\text { personell med tilstrekkelig kompetanse. } \\
\text { Overflytting til sykehus ble sett på som } \\
\text { et symbol på god behandling og en } \\
\text { verdig død. }\end{array}$ & $\begin{array}{l}\text { Sykehusinnleggelse ble relatert til } \\
\text { akutt sykdom og sykehuset ble sett på } \\
\text { som bedre istand til å lindre ubehage- } \\
\text { lige symptomer enn sykehjemmet. }\end{array}$ & $\begin{array}{l}\text { Kunnskap innen symptomlindring og } \\
\text { god kommunikasjon mellom pårørende } \\
\text { og personalet er viktig for at pårørende } \\
\text { skal oppleve at deres nære får en verdig } \\
\text { død ved sykehjem. }\end{array}$ \\
\hline Lillemoen, m.fl. (28) & $\begin{array}{l}\text { Prosjektets målsetting var faglig kom- } \\
\text { petanseutvikling i relasjon til døende } \\
\text { pasienter og deres pårørende med hjelp } \\
\text { av Liverpool Care Pathway (LCP) som } \\
\text { et redskap for kvalitetssikring av omsor- } \\
\text { gen ved livets slutt. }\end{array}$ & $\begin{array}{l}\text { Bruk av tiltaksplanen sikrer god obser- } \\
\text { vasjon og symptomkontroll i terminal- } \\
\text { fasen, og sikret kontinuitet i den } \\
\text { lindrende behandling og omsorg samt } \\
\text { systematisk dokumentasjon. }\end{array}$ & $\begin{array}{l}\text { Prosjektet viser et behov for å sikre at } \\
\text { tiltaksplanen også finnes i elektronisk } \\
\text { versjon, slik at den kan bygges inn i det } \\
\text { ordinære dokumentasjonssystemet } \\
\text { som benyttes. }\end{array}$ \\
\hline Paulsen, m.fl. (29) & $\begin{array}{l}\text { Implementering av LCP i institusjoner } \\
\text { og hjemmebasert omsorg for å kvali- } \\
\text { tetssikre omsorgen til døende og deres } \\
\text { pårørende, samt å bedre dokumenta- } \\
\text { sjonen. }\end{array}$ & $\begin{array}{l}\text { Ved å ta i bruk LCP ved forventede } \\
\text { dødsfall vil god behandling og omsorg } \\
\text { bli satt i system, uavhengig av perso- } \\
\text { nenes diagnose eller oppholdssted. }\end{array}$ & $\begin{array}{l}\text { Behovet for optimal symptomlindring } \\
\text { i livets sluttfase er ikke et nytt tema, } \\
\text { men innføring av LCP har gitt øket } \\
\text { bevissthet om temaet. }\end{array}$ \\
\hline Morita, m.fl. (30) & $\begin{array}{l}\text { Spesiell symptom- behandling rettet } \\
\text { mot tungpust, tretthet og hjelp med } \\
\text { beslutningsprosesser, ved hjelp av til- } \\
\text { passede modeller og rehabiliteringspro- } \\
\text { gram-mer synes å være viktig. }\end{array}$ & $\begin{array}{l}\text { Studien viser at et palliativt omsorgs- } \\
\text { program for eldre pasienter må foku- } \\
\text { sere på daglige aktiviteter for å } \\
\text { fremme en følelse av glede og sosialt } \\
\text { samspill, samt rehabilitering for å opp- } \\
\text { rettholde vavhengighet. }\end{array}$ & $\begin{array}{l}\text { Eldre døende pasienter trenger minst } \\
\text { samme nivå av palliativ omsorg som } \\
\text { pasienter i andre aldersgrupper. Disse } \\
\text { pasientene opplevde høyere grad av } \\
\text { tap av håp, glede og uavhengighet enn } \\
\text { yngre pasienter, under } 70 \text { år. }\end{array}$ \\
\hline
\end{tabular}

TABELL 4: Tiltak/omsorg i forhold til eldre døende.

\section{«Det er stor enighet om betydningen av en helhetlig tilnærming og omsorg.॥}

Denne studien fant at dette kunnskapsfeltet mangler beskrivelser av eldre døende pasienters opplevelse av dødsangst. Dette kan tyde på at dødsangst kanskje oppleves som vanskelig for sykepleierne og annet helsepersonell. Den helhetlige omsorgen for døende eldre pasienter må være basert på en beskrivelse av hvordan dødsangst kan arte seg hos denne gruppen, og hva som kan være med på å lindre den.

Med tanke på det fokus verdighet hadde i alle de inkluderte artiklene, kan det være nærliggende å anta at de spesifikke begrepene som angir innholdet i verdighet vil være av avgjørende betydning også når en skal lindre dødsangst. Videre viser denne studien at det er stor enighet om betydningen av en helhetlig tilnærming og omsorg til døende pasienter, og at konkrete elementer i denne helheten er verdighet, samt god dokumentasjon, kommunikasjon, symptomlindring og kompetanse. Disse elementene framstår som avgjørende for å kunne tilrettelegge og bidra til den «gode død» blant eldre døende mennesker. 


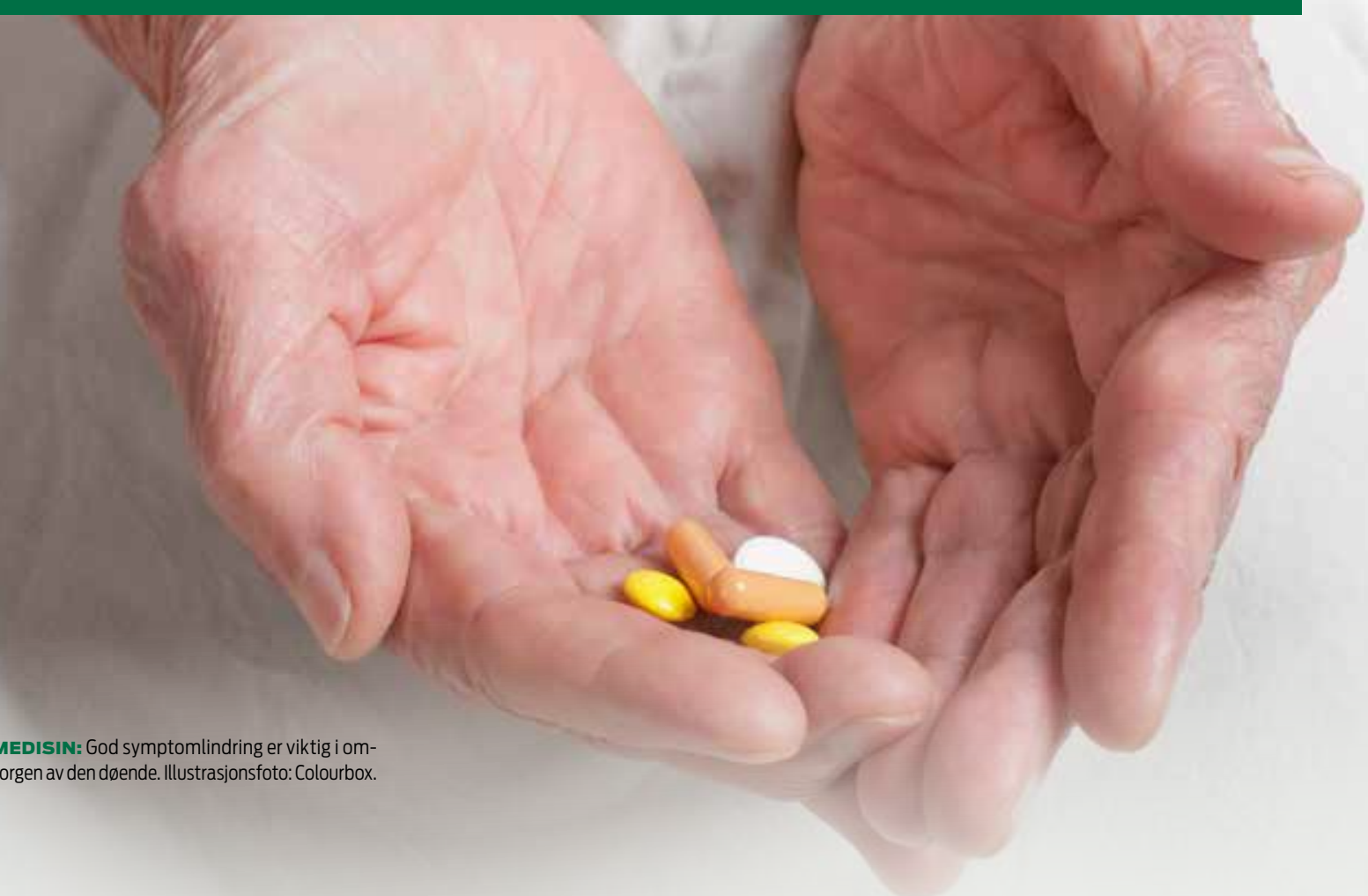

MEDISIN: God symptomlindring er viktig i omsorgen av den døende. Illustrasjonsfoto: Colourbox.

\section{Referanser:}

1. Statistisk sentralbyrå. Dødssted. 2011, tabell 03297.

2. Husebo BS, Husebo S. MEDISIN OG VITENSKAP-Tema: Sykehjemsmedisin-Sykehjemmene som arena for terminal omsorg--hvordan gjor vi det i praksis? Tidsskr Nor Laegeforen. 2005;125(10):1352-4.

3. Gjerberg E, Bjørndal A. Hva er en god død i sykehjem? Sykepleien Forskning. 2007;2(2):174-80.

4. Kaarbø E. Bedre omsorg mot slutten. Sykepl Fag. 2008;96(9):72-4.

5. Henderson V. Basic principles of nursing care: Amer Nurses Pub; 1997.

6. Saunders C. On dying and dying well. ProcRSocMed. 1977;70(4):290-1.

7. Ringdal G, André B. The Importance of Palliative Care for Terminally III Cancer Patients and their Family Members. J Palliat Care Med. 2014;4(176):2.

8. Emanuel EJ, Emanuel LL. The promise of a good death. The Lancet. 1998;351, Supplement 2(0):SII21-SII9.

9.Field MJ, Cassel CK. Approaching Death: Improving Care at the End of Life: National Academies Press; 1997.

10.Shrut SD. Attitudes toward old age and death. Ment Hyg. 1958;42(2):259.

11. Feifel H. Attitudes of mentally ill patients toward death. The Journal of nervous and mental disease. 1955;122(4):375-80.

12.Caprio FS. A study of some psychological reactions during prepubescence to the idea of death. Psychiatr Q. 1950;24(3):495-505.

13.Pollak JM. Correlates of death anxiety: A review of empirical studies. OMEGA--Journal of Death and Dying. 1979;10(2):97-121.

14. Gesser G, Wong PT, Reker GT. Death attitudes across the life-span: The development and validation of the Death Attitude Profile (DAP). OMEGA - Journal of Death and Dying. 1987;18(2):113-28.

15.Broome ME. Integrative literature reviews for the development of concepts. Concept development in nursing: foundations, techniques and applications Philadelphia: WB Saunders Company. 2000:231-50.

16. Whittemore R, Knafl K. The integrative review: updated methodology. J Adv Nurs. 2005;52(5):546-53.

17. Glasziou P, Irwig L, Bain C, Colditz G. Systematic reviews in health care: Cambridge University Press, Cambridge, UK; 2001.
18.Kvale S. Interviews. An Introduction to Qualitative Research Interviewing. Thousand Oakes, London, New Delhi: SAGE Publications; 1996.

19.Miles MB, Huberman AM. Qualitative Data Analysis1994.

20. Franklin L-L, Ternestedt B-M, Nordenfelt L. Views on dignity of elderly nursing home residents. Nurs Ethics. 2006;13(2):130-46.

21. Depaola SJ, Griffin M, Young JR, Neimeyer RA. Death anxiety and attitudes towardthe elderly among older adults: The Role of gender and ethnicity. Death Stud. 2003;27(4):335-54.

22. Drageset J, Eide GE, Kirkevold M, Ranhoff AH. Emotional loneliness is associated with mortality among mentally intact nursing home residents with and without cancer: a five-year follow-up study. J Clin Nurs. 2013;22(1-2):106-14.

23. Midtbust MH, Lykkeslet E, Skovdahl K. «Med mobilen i lomma» Pårørendes erfaringer når en av deres nære dør i sykehjem. Nordisk tidsskrift for helseforskning. 2011;7(1):77-90.

24. Strömberg A, Jaarsma T. Thoughts about death and perceived health status in elderly patients with heart failure. European journal of heart failure. 2008;10(6):608-13.

25. Tsai J-S, Wu C-H, Chiu T-Y, Hu W-Y, Chen C-Y. Fear of Death and Good Death Among the Young and Elderly with Terminal Cancers in Taiwan. J Pain Symptom Manage. 2005;29(4):344-51.

26. Cheng SY, Hu WY, Liu WJ, Yao CA, Chen CY, Chiu TY. Good death study of elderly patients with terminal cancer in Taiwan. Palliat Med. 2008;22(5):626-32.

27. Steindal S, Sørbye, LW. Er sykehjemmet et verdig sted å dø? Sykepleien Forskning. 2010;5(2):138-45.

28. Lillemoen L, Velund RU, Østenvik E. Tiltaksplan for døende pasienter. Sykepl Fag. 2011;99(1):60-3.

29. Paulsen SR, Elvestuen, I L, Edler-Woll T, M, Andersson AM, AbrahamsenJ. Kvalitetssikrer omsorg for dødende. Sykepl Fag. 2014;102(6):58-61.

30. Morita T, Kuriya M, Miyashita M, Sato K, Eguchi K, Akechi T. Symptom Burden and Achievement of Good Death of Elderly Cancer Patients. J Palliat Med. 2014;17(8):887-93. 


\section{Samhandling}

\section{- sykepleieledere og bestiller-utførerenhet}
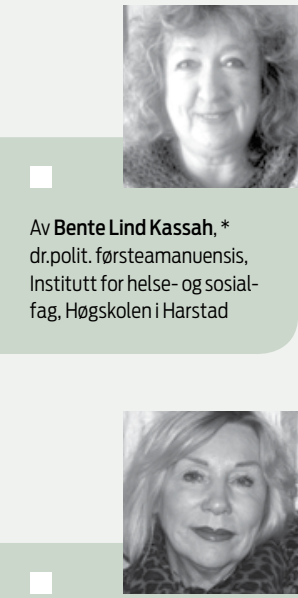

Av Wivi-Ann Tingvoll,* førstelektor, Avdeling for helse- og samfunnsfag. Høgskolen i Narvik

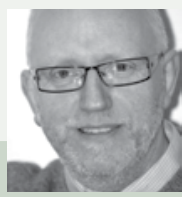

Av Sven-Tore Dreyer Fredriksen, DrPH førsteamanuensis, Avdeling for sykepleie- og helsefag, Profesjonshøgskolen, Universitet iNordland

\section{Introduksjon}

Antall eldre personer over 80 år vil øke fra 218584 i

2007 til over 500000 i 2050 (St.meld. nr. 47 (20082009), 2009). I gruppen eldre som er åtti år eller mer, mottok 55 prosent pleie- og omsorgstjenester i 2010 (Helsedirektoratets omsorgsstatistikk, 2010). Dette er en utfordring for de kommunale pleie- og omsorgstjenestene, noe som gjenspeiles i offentlig helse- og omsorgspolitikk (St.meld. nr. 45 (20022003).

I 2012 ble samhandlingsreformen implementert (St.meld. nr. 47. 2008-2009), og i 2013 ble regjeringens innovasjonsstrategi (Kommunal- og regionaldepartementet, 2013) lagt frem. En viktig målsetting i disse dokumentene er at det fremdeles skal tilbys faglige gode tjenester til tross for den sterke økningen i antall eldre. Samtidig vektlegges økt fokus på pasienters myndiggjøring. Med pasientmedvirkning menes at; «De som berøres av en beslutning, eller er brukere av tjenester, får innflytelse på beslutningsprosesser og utforming av tjenestetilbud» (St.meld.nr. 34. 1996-1997).

Studier om prioriteringer i hjemmesykepleien viser at sykepleierne opplever nettopp det å opprettholde en ønsket faglig standard som en utfordring, og at det å imøtekomme alle pålagte krav er konfliktfylt (Aroskar, Moldow, \& Good, 2004;
Siri Tønnessen, 2011; Kassah, Tingvoll \& Kassah, 2014). I denne artikkelen rettes fokus mot tildeling av tjenester i pleie- og omsorgstjenesten, fordi tildelingsvedtak har betydning for hvordan den enkelte eldre blir ivaretatt i en pleie- og omsorgstjeneste som er under press.

Bestiller-utførermodellen har fått en sentral plass i organiseringen av pleie- og omsorgstjenester i kommunene (Vanebo, Klausen, \& Busch, 2011) og er en del av New Public Management (Bush og Vanebo, 2005). New Public Management (NPM) bygger på teorier og modeller for styring i privat sektor, samt på modeller for markedsstyring, som for eksempel konkurranse om levering av offentlige tjenester (Lian, 2007). Flere kommuner etablerte en egen bestillerenhet da bestiller-utførermodellen ble innført (Bush \& Vanebo, 2005). Ansatte i bestillerenheten besitter myndighetsutøvelsen i tildelingsprosessen, vurderer behov, fatter vedtak om tildeling og bestiller tjenester til den enkelte bruker av pleie- og omsorgstjenester i kommunen. Tildelingsenheten har også plikt til å evaluerer vedtak om tjenester fordi vedtakene er enkeltvedtak (Lov om forvaltning, 1967). Tjenester som tildeles kan være i eget hjem eller plassert i sykehjem (Sosial- og helsedirektoratet, 2004). Tildelingsenheten ivaretar også kontakten mellom sykehus og kommunes

\section{Abstract}

The social support and care units of municipalities provide the contextual base for this study that focuses on the experiences of nursing leaders and their interaction with the services allocation unit. The article aims at contributing to knowledge on how the "service user/service provider» model affects the influence that nursing leaders in a municipality have on service allocation processes, and the views of nursing leaders on how the needs of elderly patients are met in the process of service allocation. The study's methodological base is the phenomenological-hermeneutical approach. We acquired data for the study using focus groups. The findings indicate that the adoption of the «service user/ service provider» model in the municipality's social support and care services contribute to formalizing, and therefore providing a transparent service distribution process. The finding also show that there are changes in decision-making authority of nursing leaders and their possibility to meet the individual needs of their patients.

Søkeord: Bestiller-utførermodell, makt, kompetanse, endrete pleie- og omsorgsbehov, kontinuitet. 
BEHOV:Sykepleielederneser hvilke behov pasientene har for omsorg. Illustrasjonsfoto: Colourbox.
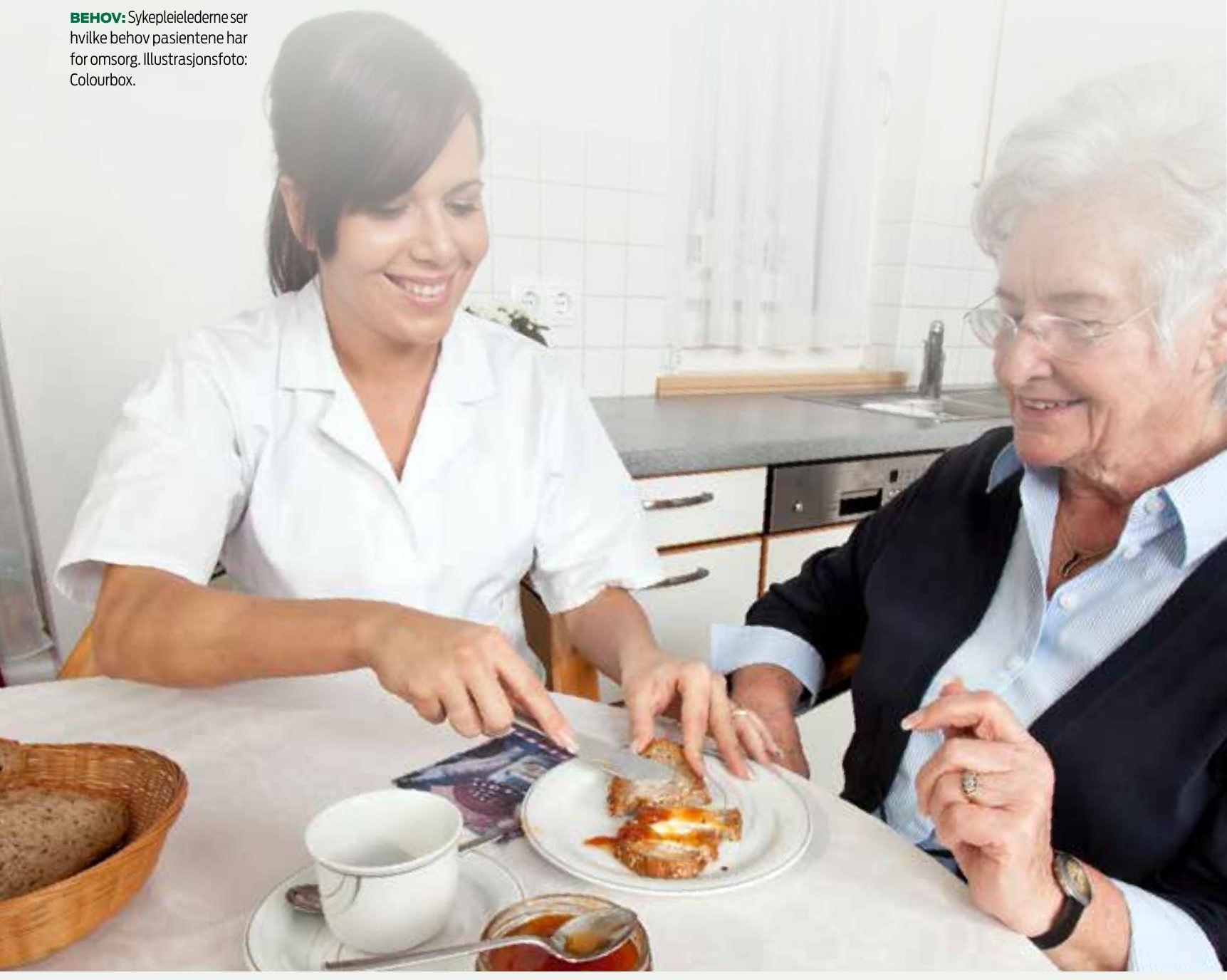

pleie- og omsorgstjeneste. Lokale enheter i pleieog omsorgstjenesten har de utførende oppgaver.

Det ligger flere motiver bak innføringen av bestiller-utførermodellen. Økt effektivitet og ressursbesparelser er viktig (Kirchoff, 2010), og man ønsker også å redusere den profesjonelle kontrollen og få til individuelt tilpassete tjenester (Henriksson et al., 2006). Det søkes videre å utvikle et tydelig innhold og kvalitet i omsorgstjenestene (Sosialog helsedirektoratet, 2004; Stamsø \& Hjelmtveit, 2009). En undersøkelse viser at det er de effektivitetsfremmende elementer som fått størst gjennomslag i praktiseringen av modellen (Kommunenes sentralforbund, 2012).

Vektleggingen på effektivitet kan ha sammenheng med ressursmangel i den kommunale omsorgstjenesten, noe som fører til at kvaliteten på tjenestene senkes (Aroskar et al., 2004; Nortvedt et al., 2008; Varcoe et al., 2004). Kirschoff (2010) sier at vedtakene om tildeling av tjenester først og fremst handler om antall besøk, uten at innholdet $i$ arbeidet er definert, noe som kan ha betydning for kvaliteten i tjenestetilbudet i pleie- og omsorgstjenesten. Manglende prioriteringsveiledere, etiske retningslinjer eller kriterier for prioritering

\section{«Noen opplever å bli hørt, mens andre i liten grad når frem.॥}

i pleie- og omsorgstjenestene er også en utfordring (Tønnessen, 2014). Dette er problematisk for ansatte i pleie- og omsorgstjenesten som skal utføre faglig forsvarlige sykepleietjenester. Her benyttes faglig forsvarlige sykepleietjenester, som det å beskytte pasienter mot handlinger som ikke er i samsvar med normer om faglig forsvarlig praksis (Norsk Sykepleierforbund, 2008, i Tønnessen 2014). 
I denne artikkelen belyses samhandlingen mellom sykepleieledere i den kommunale pleieog omsorgstjenesten og den kommunale tildelingsenheten. Det diskuteres hvordan sykepleielederne opplever sin posisjon i samhandlingen, om det er samsvar mellom vedtak og de eldre pasientenes pleie- og omsorgsbehov, samt sykepleieledernes mulighet for å ivareta eldre pasienter når de skal utføre vedtatte tjenester. Hensikten med artikkelen er å utvikle kunnskap om hvordan bestiller-utførermodellen påvirker sykepleielederes mulighet for å utøve innflytelse over tildelingsprosessene, og hvordan sykepleielederne opplever at eldre pasienters pleie- og omsorgsbehov blir ivaretatt i tildelingsprosessene. Videre i artikkelen gis det først en redegjørelse for teoretisk ressurs, en beskrivelse av felt og metode, samt presentasjon av data og diskusjon. Artikkelen avsluttes med en kort oppsummering.

\section{Teoretisk ressurs}

En formell organisasjonsstruktur kan betraktes som organisasjonens arkitektur. Den er designet for at aktører skal ivareta sine oppgaver (Senge, 1990). Selznick (1984) omtaler strukturer i en organisasjon som både formelle og uformelle. Uformelle strukturer består av normer og hierarkier av mennesker,

\section{"Il samtalene kom det frem nyanserte opplevelser..»}

og eksisterer sammen med formell struktur. Den formelle organiseringen av for eksempel informasjon og kommunikasjon i den kommunale pleie- og omsorgstjenesten er viktig, spesielt for kontinuiteten i pasientforløpet når tildelingskontoret fatter vedtak. Her er det den administrative kontinuitet, som blant annet omfatter informasjonsdeling mellom team, profesjoner og yrkesutøvere, og den informative kontinuitet som innebærer at relevant informasjon om pasienten alltid er tilgjengelig, som er interessant (Freeman et al., 2007). Samhandling er viktig for at administrativ og informativ kontinuitet kan ivaretas. Ifølge Orvik (2004) har samhandling en forpliktende dimensjon, og tillit og respekt betraktes som nødvendig for at samhandlingen skal lykkes. Det er behov for omfattende og bred kompetanse i bestillerenheten innenfor behovskartlegging, kontraktsforhandlinger (vedtak), styring og tjenesteproduksjon (Busch og Vanebo, 2011).

Samhandlingen vil være påvirket av både for- melle og uformelle maktposisjoner i helsetjenesten. Weber definerer makt som: «ett eller flere menneskers sjanse til å sette gjennom sin egen vilje i det sosiale samkvem, og det selv om andre deltakere i det kollektive liv skulle gjøre motstand» (Weber, Fivelsdal, \& Østerberg, 2010). Ifølge Engelstad (1999) beskriver makt ubalanse i relasjoner mellom aktører, og makt betraktes som det å bringe frem sosial endring. Det handler om evnen til å få noe til å skje (Engelstad, 2009). Definisjonsmakt kan forstås som en aktørs mulighet til å påvirke hvordan andre oppfatter de meninger som vedkommende forfekter. Dette innebærer at selv om det kan være konkurrerende definisjoner av en situasjon, vil personen med definisjonsmakt få gjennomslag for sine tanker og ideer (Bourdieu \& Prieur, 1996). Maktens konsekvenser er avmakt og motmakt, og avmakt oppleves når det ikke er betingelser for å utføre virkningsfulle handlinger (Hernes, 2012).

\section{Felt og metode}

Kommuneledelsen i en middels stor bykommune ble tilskrevet med forespørsel om intervju av sykepleieledere for sykehjem og hjemmesykepleie. Søknaden ble innvilget. I kommunen der undersøkelsen fant sted er det en tildelingsenhet som har ansvar for å forvalte oppgavene i pleie- og omsorgstjenesten. Ansatte ved tildelingsenheten vedtar og tildeler tjenester til eldre pasienter som har et pleie- og omsorgsbehov. Sykepleieledere i sykehjem og hjemmesykepleien mottar vedtakene og iverksetter disse.

Det ble invitert 22 sykepleieledere med 3-15 års erfaring, og alle svarte positivt på henvendelsen. Informantene ga informert samtykke og ble informert om at de kunne trekke seg fra undersøkelsen når som helst. Informantene ble valgt fordi de innehar overordnet ansvar for driften av pleie- og omsorgstjenesten. Sykepleielederne skal legge til rette for og etterse at vedtakene fra tildelingsenheten blir gjennomført, og har ansvar for å ta kontakt med tildelingsenheten ved endring i eldre pasienters pleie- og omsorgsbehov.

Det ble benyttet fokusgrupper som datasamlingsmetode (Wibeck, 2011). Dette fordi diskusjoner omkring avgrensete temaer gir muligheter for nyansert informasjon om informantens opplevelser. Diskusjoner kan gi rom for utvikling av kunnskap som kanskje ikke hadde framkommet i personlige intervjuer fordi gruppedynamikk kan påvirke informantenes refleksjonsprosesser (Ibid, 2011). Det ble dannet fire fokusgrupper, to med ledere fra 

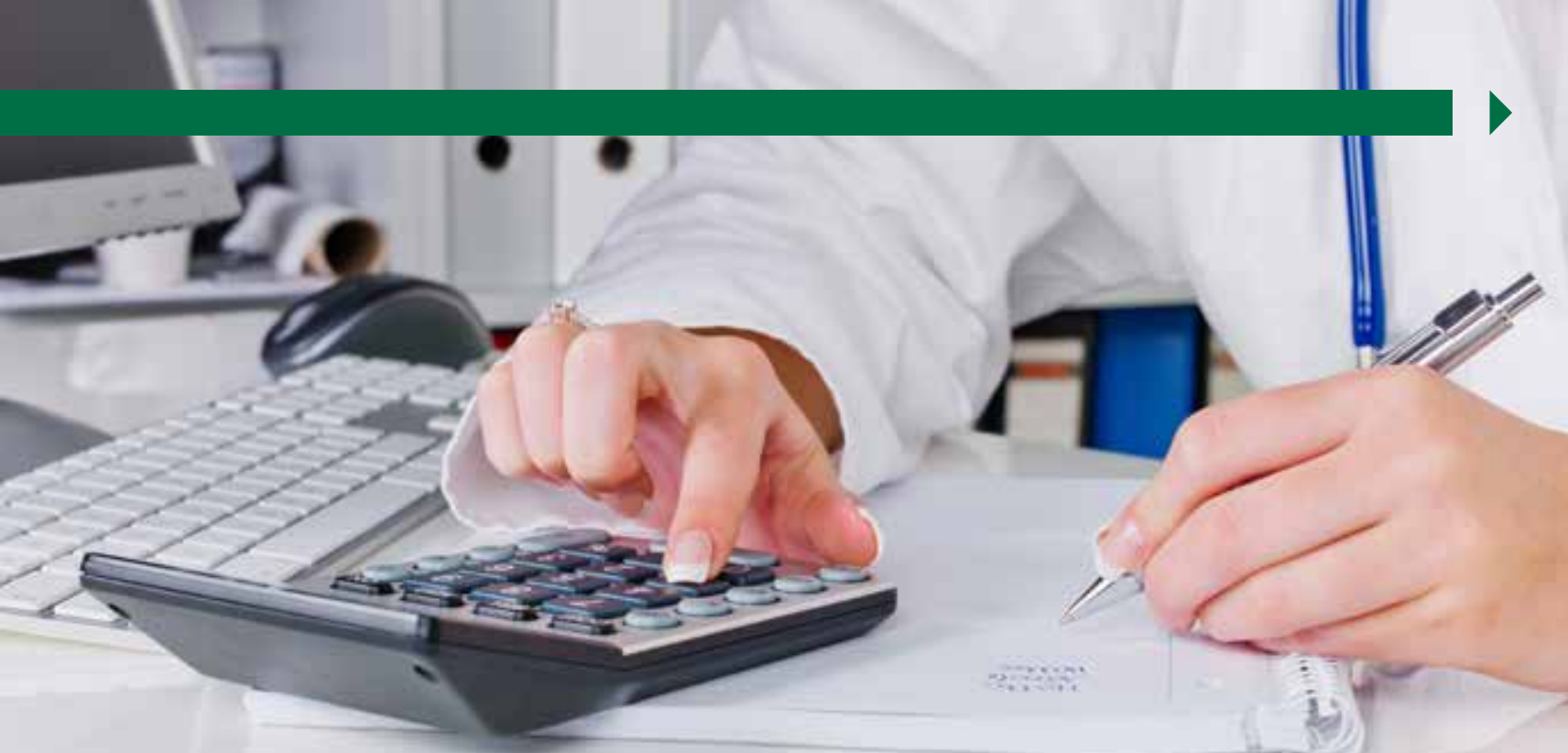

SPARING: New Public Management bringer markedstenkning inn i helsetjenesten. Illustrasjonsfoto. Colourbox.

sykehjem og to med ledere fra hjemmesykepleien. Temaene i de første fokusgruppene omhandlet tildeling av tjenester ved utskrivelse av eldre pasienter med sammensatte behov fra sykehus til pleie- og omsorgstjenesten. Data fra de første fokusgruppene ble analysert, og det framkom utfordringer knyttet til samhandlingen i tildelingsprosessen. Dette ble tema for diskusjonene i andre runde i fokusgruppene. I samtalene kom det frem nyanserte opplevelser, samtidig som felles erfaringer utkrystalliserte seg. Det er mulig at informantene holdt tilbake informasjon som de ikke ønsket å dele i gruppen, noe som kan innebære tap av data. Samtalene i fokusgruppene ble tatt opp på bånd og transkribert. Dataene er analysert ved hjelp av Lindseth og Norbergs fenomenologisk-hermeneutisk forståelse (Lindseth \& Norberg, 2004). Studien er godkjent av Norsk samfunnsvitenskapelig datatjeneste.

\section{Empiriske funn og diskusjon}

Det overordnete temaet som framkom i analysen er at bestiller-utførermodellen i den kommunale pleieog omsorgstjenesten bidrar til formalisering og endring i beslutningsmyndighet og i mulighetsrommet for å ivareta eldre pasienters pleie- og omsorgsbehov. Dette framkom gjennom følgende subtema; endring i beslutningsmyndighet, behov for samhandlingsarena, oversiktlig tildelingsprosess og at organiseringen påvirker ivaretakelsen av pasienter.

\section{Formalisering og beslutningsmyndighet}

Informantene gir uttrykk for at tildelingsenhetens sentrale funksjon har bidratt til en forutsigbar tildelingsprosess. En informant sier det slik: «Vi har opplevd den gamle og den nye ordningen. Det er mindre komplisert nå. Vi har en fast adresse vi kan henvende oss til».Funnene viser videre at tildelingsprosessen er mindre ressurskrevende enn tidligere og oppleves som ressursbesparende og konfliktdempende. En informant omtaler tidligere bruk av ressurser og sier: «Før var det lederne i sykehjem og åpen omsorg som satt $i$ vedtaksteam og valgte ut hvem som skulle få plass, men nå får de bare beskjed ... Vi brukte mye mer ressurser i denne tildelingen før. Det var fellesmøte hver uke, så var det møte i distriktet hvor det var vi som sendte ut vedtaket». En annen informant sier: «Det var tidligere konflikter når vi var presset og hadde mange tunge pasienter». En tredje vektlegger: «Det har lettet tjenesten og tjenesteutøvelse som er ute i hjemmesykepleien. Vi har fät tid til andre oppgaver. I den modellen vi hadde før var det en dragkamp mellom hjemmesykepleien og institusjonen om hvem som skulle ha lette brukere osv. Mye tid gikk med til å drøfte dette ikke bare på ledernivå, men også på tjenestenivå. Det unngår vi nå. Vi får tildelt brukeren etter de vurderinger som er gjort på et sentralt kontor og det blir en rettferdig fordeling og de som trenger tjenesten faktisk får det».

Dette kan forstås som om at bestiller-utførermodellen bidrar til å forenkle og formalisere tildelingsprosessen, blant annet fordi det er innført en fast adresse for henvendelser og vedtak angående tjenester i pleie- og omsorgstjenesten. Bestillerutførermodellen har ført til endringer i den formelle organisasjonsstrukturen. Tildelingsenheten fungerer som et bindeledd mellom spesialisthelsetjenesten og kommunehelsetjenesten, samt mellom omsorgsenhetene i kommunen. Dette kan bety at bestiller-utførermodellen bidrar til at det utvikles formelle strukturer (Selznick,1984) som gir en klar 
enter kommer hjem etter korttidsopphold og kan bo hjemme lengst mulig. Eldre som bor i egne hjem kan opprettholde sine sosiale nettverk, samtidig som det kan oppleves som trygt å leve i kjente omgivelser. Den eldre som har et sosialt nettverk kan snakke om opplevelser og begivenheter som har vært, og er viktige i den enkeltes liv (Daatland, 2008). Dette kan styrke den eldres identitet og selvfølelse (Daatland \& Solem, 2011; Gurgens, Sagen \& Solbjørg, 2014). Flere korttidsplasser kan bidra til sterkere myndiggjøring (Kassah \& Kassah, 2009) hvis pasienten ønsker å bo hjemme.

Funnene viser også at eldre ønsker å bo i sykehjem fordi de er utrygge og ensomme i sine hjem. Dette kan ha sammenheng med at når hjemmetjenesten presses er det spesielt tiden som brukes til kommunikasjon og personlig omsorg som reduseres (Bowers, Lauring, \& Jacobson, 2001; Parry-Jones \& Soulsby, 2001; S. Tønnessen, 2011), og pasienters åndelige behov nedprioriteres (Nortvedt et al., 2008). Ventetid for å få fast sykehjemsplass kan medføre redusert myndiggjøring og livskvalitet. Sykepleielederne vektlegger at situasjoner preget av et presset tjenestetilbud og lang ventetid er belastende både for pasienter og ansatte $\mathrm{i}$ pleie- og omsorgstjenesten. Dette kan betraktes som en avmaktssituasjon (Hernes, 2012), fordi sykepleielederne har ikke betingelser for å utføre virkningsfulle handlinger for å bedre eldre pasienters situasjon. Det kan derfor stilles spørsmål om tildelingsenhetens definisjonsmakt tjener pasienter og ansatte i pleie- og omsorgstjenesten når behovene endrer seg etter førstegangsvedtak. Annen forskning viser også at det er utfordrende for tildelingsenheten å gjøre vedtak som tar hensyn til raske endringer i behovet for tjenester (KS, 2012).

\section{Samhandling når pleie- og omsorgsbehovet endres}

Empirien viser at sykepleielederne ofte må kontakte ansatte ved tildelingsenheten for å endre tildelte tjenester når pleie- og omsorgsbehov endrer seg. Sykepleielederne vektlegger at de er avhengige av at tildelingsenheten lytter når eldre pasienters pleieog omsorgsbehov endres hvis de skal kunne gi faglig forsvarlige tjenester (Tønnessen, 2011; 2014). Funn viser at sykepleielederne har forskjellig erfaring med hvor lydhør ansatte i tildelingsenheten er når de søker å ta kontakt for å ivareta endringer etter førstegangsvedtak. En informant sier: «Vi er avhengige av at tildelingskontoret lytter til oss og ser nødvendigheten av å endre ressursene til den eldre pasi- enten når det er behov for det». En annen vektlegger: «Skulle det dukke opp spørsmål i ettertid [...] tar vi kontakt med tildelingskontoret og setter oss sammen med dem og pårørende og ser på det». Dette viser at sykepleielederne kan initiere dialog hvis de ut fra faglig skjønn opplever at eldre pasienter får endring i pleie- og omsorgsbehov. Bestiller-utførermodellen kritiseres for å redusere mulighetene for å utøve faglig skjønn, noe som kan vanskeliggjøre det å ta individuelle hensyn og å gi helhetlige tjenester (Tønnessen, 2011; 2014). Her tyder det imidlertid på at uformell kommunikasjon og uformell samhandling til en viss grad ivaretar sykepleieledernes mulighet for å bli hørt når de utøver faglig skjønn (Ibid, 2011; 2014) etter førstegangsvedtak.

Andre sykepleieledere opplever det å få kontakt med tildelingsenheten som utfordrende,og en sier: «Vi får dem sjelden i tale så vi prøver å ordne opp så godt som vi kan». Formelt etablerte kommunikasjonsstrukturer som i liten grad fungerer, eller fravær av sådanne, gir disse sykepleielederne en svak stemme når de krever å bli hørt, noe som kan ha negativ innflytelse på deres evne til å få noe til å skje (Engstad, 2009). Sykepleielederne kan bli avhengig av personlige tillitsrelasjoner og/eller av at ansatte i tildelingsenheten evner å imøtekomme deres forespørsler. Funnene viser at i slike situasjoner tar sykepleielederne ansvar og gir de pleie- og omsorgstjenester de har mulighetsrom for, samtidig som hjemmetjenesten har begrensete ressurser (Siri Tønnessen, 2011). Uten formelle kommunikasjonsstrukturer som fungerer kan ordningen bidra til at deres innspill i liten grad blir tatt til etterretning og pasienten kan bli skadelidende. Både sykepleieledernes ledelsesposisjon og eldre pasienters myndiggjøring (Kassah og Kassah, 2009) kan sies å være svekket i denne sammenhengen. Dette er betenkelig fordi myndiggjøring styrker den eldres pasients identitet

\section{«Sykepleieledere opplever det å få kontakt med tildlings- enheten som utfordrende.॥}

og livskvalitet. Skal medvirkning praktiseres, må den som benytter tjenesten være delaktig, og tradisjonelle maktforhold der helsepersonell tar de fleste beslutninger må endres (Askim, Rohweder, Lydersen, \& Indredavik, 2004). 
Samhandling (Orvik, 2004) mellom sykepleieledere og ansatte i tildelingsenheten er nødvendig fordi aktørene ved tildelingsenheten er avhengige av tjenesteutøvernes observasjoner og vurderinger av tildelte tjenester i forhold til pleie- og omsorgsbehov. Mangelfull samhandling vil gjøre det vanskelig å ivareta den administrative og informative kontinuiteten (Freedman et. Al 2007), som er nødvendig for å sikre faglig forsvarlighet (Tønnessen 2011; 2014). En del kommuner har endret praksis fra tidfestete vedtak til tjenestebeskrivende tiltak for å inkludere det faglige skjønn, og tjenesteyternes skjønnsmessige vurdering av tjenestemottakers behov har fått en sterkere plass (KS).

\section{Behov for flerfaglig samhandling}

Ifølge informantene er det behov for økt faglig kompetanse for å få til et helhetlig tilbud til den eldre pasient. Dette fordi endringene i kjølvannet av samhandlingsreformen bidrar til at kommunene har ansvar for eldre pasienter med mer sammensatte og komplekse lidelser enn tidligere (Tingvoll, Kassah \& Kassah, 2014). Kompetanseutfordringene møtes med at ansatte i pleie- og omsorgstjenesten henvender seg til spesialisthelsetjenesten. En informant sier: «Nei, sykehjemmet har ingen kontakt med de pasienter som ligger på sykehuset, hvis det da ikke er prosedyrer eller annen opplœring som er nødvendig. Da er det slik at vi drar opp til sykehuset for å loere det, eller det kan vore personell fra sykehuset som kommer hit». Personalet får da praktisk opplæring i spesielle prosedyrer, sammensatte sykdomstilstander og truende funksjonssvikt. Svakheten ved

\section{«Det er behov for styrket samhandling.»»}

en slik ordning er at personalet ofte ikke får tilgang på den dybdekunnskapen som de har behov for når de skal gi faglig forsvarlige tjenester (Tønnessen, 2011). Dybdekunnskap gir analytiske redskaper for å vurdere komplekse situasjoner og omfatter mer enn den tekniske kunnskapen som formidles i kortere opplæringsøkter. Det kan stilles spørsmål ved om slike ordninger innfrir kravene i helsepersonelloven om faglig forsvarlighet (Lov om helsepersonell, 2012).

Sykepleielederne uttrykker at bestillerutførermodellen har gitt utfordringer i relasjon til fastlegene som de mener ofte har liten innsikt i tildelingsprosessene. En informant sier: «Det som jeg opplever er at det henger igjen hos fastlegen. De sier at ho fru Hansen må ha sykehjemsplass. Jeg må si at de vet ikke bedre. Det er verken fastlegen eller sykehuset som tildeler tjenesten eller det nivået ho skal på i pleie- og omsorgstjenesten». Utsagnene kan forstås som at det mangler en felles forståelse av tildelingsprosessen. Fastleger kan ha svak innsikt i hvor vurderings- og beslutningsmyndigheten i organisasjonen ligger, noe som tyder på at det er behov for å etablere formelle kommunikasjonsstrukturer som involverer også disse aktørene hvis den administrative og informative kontinuitet skal ivaretas (Freeman et al., 2007).

Manglende samhandlingsarenaer og aktørens behov for samhandlingskompetanse (Orvik, 2004) er en utfordringer i tildelingsprosessen. Fastleger som ikke henvender seg til riktig instans, kan bidra til at uformelle strukturer som opprettholder dysfunksjonelle formelle strukturer knyttet til enkeltvedtak i pleie- og omsorgstjenesten vedlikeholdes.

\section{Oppsummering}

I artikkelen belyses samhandlingen mellom sykepleieledere i den kommunale pleie- og omsorgstjenesten og den kommunale tildelingsenheten. De empiriske funn viser at tildelingsenheten fungerer som et bindeledd mellom spesialist- og kommunehelsetjenesten. Dette ser ut til å gi en klar ansvarsog oppgavefordeling, noe som kan tyde på at det er utviklet en instrumentell kompetanse (Orvik, 2004) ved førstegangsvedtak i tildelingsenheten. Bestiller-utførermodellen bidrar til en formalisert tildelingsprosess som virker ressursbesparende og konfliktdempende.

Empirien viser videre at endring fra faste langtidsplasser i sykehjem til korttidsplasser både har positive og negative følger for den eldre pasienten. De som ønsker det kan bo i eget hjem lengre enn tidligere, mens de som er engstelige og ønsker langtidsplass, opplever dette som vanskelig. Dette kan få negativ innflytelse på den eldre pasients myndiggjøring (Kassah et. al. 2009).

Studien viser videre at sykepleielederne har forskjellige opplevelser av samhandlingen med tildelingsenheten når det er behov for endring i pleieog tjenestetilbudet. Noen opplever å bli hørt, mens andre i liten grad når frem, og dette påvirker deres mulighet for å få til endringer i pleie- og tjenestetilbudet (Engstad 2009). Dette kan ha sammenheng med formelle kommunikasjonsstrukturer (Selznick, 1984) som fungerer dårlig eller ikke er til stede.

De empiriske funn viser også at det er behov 
for styrket samhandling og utvikling av en felles forståelse mellom fastleger, tildelingsenhet og sykepleieledere hvis den informative og administrative kontinuitet skal ivaretas (Freedman et al, 2007).
Studien viser også at det er behov for økt kompetanse og at kompetansebehovet løses gjennom praktisk opplæring, og den dybdekunnskap som er nødvendig blir da ofte fraværende.

\section{Referanser:}

1. Helse- og omsorgsdepartementet.Samhandlingsreformen: rett behandling - på rettsted - til rett tid. Oslo: Departementet; 2009. (St.meld. nr. 47 (2008-2009)).

2. Helsedirektoratet. Samhandlingsstatistikk. Oslo: Direktoratet; 2010. (IS-1958).

3. Sosialdepartementet. Betre kvalitet i dei kommunale pleie- og omsorgstenestene. Oslo: Departementet; 2003. (St.meld. nr.45(2002-2003).

4. Kommunal- og regionaldepartementet.Nye vegar til framtidas velferd: regjeringasin strategi for innovasjon i kommunesektoren. [internett] 2013. (lest 26.02.2014). Hentet fra: http://www.regjeringen.no/ pages/38287227/velferd.pdf.

5. Sosial- og helsedepartementet. Resultater og erfaringer fra Regjeringens handlingsplaner for funksjonshemmete og veien videre. Oslo: Departementet; 1997. (St.meld.nr. 34 (1996-1997)).

6. Aroskar MA, Moldow DG. Good CM. Nurses) Voices: Policy, practice and Ethics. Nursing Ethics. 2004; 11(3):266-276.

7. Tønnessen S. The Challenge to provide sound and diligent care: a qualitative study of nurses) decisions about prioritization and patients) experiences of the home nursing service.[PhD avh.]. Oslo: Universitetet i Oslo; 2011.

8. Tingvoll WA, Kassah BLL, Kassah AK. Helse- og omsorgstjenesten: et overblikk. I: Samhandlingseformen under lupen. Kassah BLL, Tingvoll WA, Kassah AK, red. Bergen: Fagbokforlaget; 2014. S. 17-29.

9. Busch T, Johnsen E, Klausen KK, Vanebo JO. Modernisering av offentlig sektor: trender, ideer og praksiser. 3.utg. Oslo: Universitetsforlaget; 2011.

10. Busch T, Johnsen E, Klausen KK, Vanebo JO. Modernisering av offentlig sektor. 2.utg. Oslo: Universitetsforlaget; 2005.

11. Lian OS. Når helse blir en vare: medikalisering og markedsorientering $\mathrm{i}$ helsetjenesten. Kristiansand: Høyskoleforlaget; 2007.

12. Forvaltningsloven. Lov om behandlingsmåten i forvaltningen. [internett] 1967/2014. (lest 26.02.2014). Hentet fra: http://lovdata.no/dokument/ $\mathrm{NL} /$ lov/1967-02-10?q=forvaltningsloven.

13. Sosial- og helsedirektoratet. Kvalitet i helse- og omsorgstjenestene: veileder til forskrift og kvalitet i pleie- og omsorgstjenestene. [internett]. 2004. (lest 26.02.2014). Hentet fra: http://www.helsedirektoratet.no/ publikasjoner/kvalitet-i-pleie-og-omsorgstjenesten/Publikasjoner/ kvalitet-i-pleie-og-omsorgstjenesten.pdf.

14. Kirchhoff J. De skjulte tjenestene. [Avhandling (dissertation)] Karlstad: Karlstads universitet; 2010

15. Henriksson L, Wrede S, Burau V. Understanding professional projects in welfare service work. Gender, work and organization. 2006; 13(2):174-192.

16. Stams $\emptyset$ MA, Hjelmtveit V. Velferdsstaten i endring. Oslo: Gyldendal akademisk; 2009.

17. Kommunenes sentralforbund. Kostnader og gevinster knyttet til bestiller-utfører-modellen. [internett]. 2012. (lest 28.02.2014). Hentet fra: http://public.deloitte.no/dokumenter/Deloitte_KS_rapport_080812.pdf.

18. Nortvedt P, Pedersen R, Grothe KH, Nordhaug M, Kirkevold M, Slettebo,A, Andersen $B$. Clinical prioritisations of healthcare for the aged--professional roles. J Med Ethics. 2008; 34(5): 332-335. Doi: 10.1136/ jme.2007.020693.

19. Varcoe C, Doane G, Pauly B, Rodny P, Storch JL, Mahony K, Starzomski R. Ethical practice in nursing: working the in-betweens. Journal of Advanced Nursing. 2004; 45(3): 316-325.
20. Tønnessen S. Prioritering i hiemmesykepleien/mot prioriteringskriterier i helse- og omsorgstjenestene. I: Samhandlingseformen under lupen. Kassah BLL, Tingvoll WA, Kassah AK, red. Bergen: Fagbokforlaget; 2014. S. 69-84.

21. Senge PM. The fifth discipline. New York: Doubleday; 1990.

22. Selznick P. Leadership in administration: a sociological interpretation. Berkeley, California: University of California Press; 1984.

23. Freeman GK, Woloshynovych M, Baker R, Boultan M, Guthrie B, Car J Continuity of care; what have we learned since 2000 and policy imperatives now? [internet] 2006. (lest 28.02.2014). Hentet fra: http://www. hpm.org/Downloads/Bellagio/Articles/Continuity/138-final-report.pdf.

24. Orvik A. Organisatorisk kompetanse i sykepleie og helsefaglig samarbeid. Oslo: Cappelen akademisk forlag; 2004.

25. Fivelsdal E, Østerberg D. Makt og byråkrati: essays om politikk og klasse, samfunnsforskning og verdier. Oslo: Gyldendal akademisk; 2010.

26. Engelstad F. Om makt: teori og kritikk. Oslo: Ad notam Gyldendal; 1999.

27. Engelstad F. Hva er makt? Oslo: Universitetsforlaget; 2009.

28. Bourdieu P, Prieur A. Symbolsk makt: artikler i utvalg. Oslo: Pax; 1996.

29. Hernes G. Makt - det alle ønsker og ingen vedstår seg. I: Pedersen W, Næss $\mathrm{HE}$, red. Merkesteiner i norsk sosiologi. Oslo: Universitetsforlaget; 2012.

30. Wibeck V. Fokusgrupper: om fokuserade gruppintervjuer som undersökningsmetod. Lund: Studentlitteratur; 2011.

31. Lindseth A, Norberg AA. A phenomenological hermeneutical method for researching lived experience. Scandinavian Journal of Caring Sciences. 2004; 18(2): 145-153.

32. Kassah AK, Kassah BL. Funksjonshemning: sentrale ideer, modeller og debatter. Bergen: Fagbokforlaget; 2009.

33. Beauchamp TL, Childress JF. Principles of biomedical ethics. New York Oxford:University Press; 2013.

34. Daatland SO. Aldring som provokasjon: tekster om aldring og samfunn. Bergen: Fagbokforlaget; 2008.

35. Daatland SO, Solem PE. Aldring og samfunn: innføring i sosialgerontologi. Bergen: Fagbokforlaget; 2011.

36. Gjærum RG, Sagen LM, Solbjørg HK. Kultur og helse i reminisensarbeid: om aktivt medborgerskap. I: Samhandlingsreformen under lupen. Kassah BLL, Tingvoll WA, Kassah AK, red. Bergen: Fagbokforlaget; 2014. S. 203-224.

37. Bowers BJ, Lauring C, Jacobson N. How nurses manage time and work in ling-term care. Journal of Advanced Nursing. 2001; 33(4). S.484.

38. Parry-Jones B, Soulsby J. Needs-led assessment: the challenges and reality. Health and social care in the community. 2001; 9(6):414-428.

39. Askim T, Rohweder G, Lydersen S, Indredavik B. Evaluation of an extended stroke unit service with early supported discharge for patients living in a rural community. A randomized controlled trial. Clinical Rehabilitation. (2004); 18 (3): 238-248

40. Tingvoll WA, Fredriksen SD. Individuell tilretteleggelse for eldre pasienter etter sykehusopphold. Vård i Norden.2011; 31(3): 40-44.

41. Helsepersonelloven Lov om helsepersonell m.v. [internett]. 1999/2014 (lest 26.02.2014). Hentet fra: http://lovdata.no/dokument/NL/ lov/1999-07-02-64?q=helsepersonelloven 


\title{
Folkehelse så lenge vi lever
}

\author{
Helsefremmende arbeid innebærer å styrke de faktorer som setter \\ mennesker i stand til å bevare og bedre sin helse og mestringsevne.
}

$\mathrm{V}$

i blir stadig eldre som befolkning og følgelig stadig flere eldre. Selv om de fleste eldre er friske, er de fleste syke eldre. Stadig flere kan forvente mange gode år etter oppnådd pensjonsalder. Samtidig ser vi at store sykdomskategorier så som kreft, kols, diabetes, hjerteog karsykdommer og ulike psykiske plager slår mest ut i de høye aldersgruppene. Det samme bildet tegner seg i en stadig økende flerkulturelle delen av befolkningen.

Norsk Sykepleierforbund er en stolt pådriver for godt folkehelsearbeid. Like viktig som forebyggende innsats for å hindre sykdomsutvikling er i denne sammenheng helsefremmende arbeide. Det innebærer å styrke de faktorer som setter mennesker i stand til å bevare og bedre sin helse og mestringsevne. Her står sykepleiere i en særstilling. Ikke bare er vi den klart største helseprofesjonen med og prioriteringer for sitt påvirkningsarbeid. Plattformene springer ut fra landsmøtets vedtak om føringer for denne landsmøteperioden. Politisk plattform for folkehelse tydeliggjør sykepleieres rolle og betydning i folkehelsearbeidet. Det er ikke tilfeldig at det første satsingsområdet i plattformen har fătt navnet «Folkehelse i all sykepleie». Fra vugge til grav er det viktig å ha et helsefremmende perspektiv på så vel helse- og omsorgstjenesten som på innretningen av samfunnet for øvrig. Faggruppene besitter ekspertkompetansen på hvordan dette gjøres i praksis. NSF FGD synliggjorde dette tydelig gjennom sin landskonferanse i mars under tittelen «Helsefremming og forebygging, også i geriatrien».

Eldre er utpekt som et særskilt satsingsområde i NSFs politiske plattform

\section{«Det helsefremmende perspektivet er kjernen i all sykepleietenkning »»}

omfattende ansvar i alle deler av helsetjenesten. Men det er nettopp det helsefremmende perspektivet som er kjernen i all sykepleietenkning. Det er avgjørende at denne kompetansen blir tatt i bruk i samfunnsutviklingen. Like viktig som å lete etter risikofaktorene er det å løfte frem hva som bidrar til livskvalitet og trivsel.

\section{Politisk plattform}

NSF har utarbeidet et knippe politiske plattformer for å angi tydelig retning for folkehelse. Det ligger et enormt potensial for folkehelsen ved at flest mulig eldre beholder god helse lengst mulig. God helse er da forstått som å mestre de fysiske eller psykiske belastningene som kropp og sjel utsettes for, slik helseminister Bent Høie har tatt til orde for å definere det. Geriatriske sykepleiere representerer dermed en særs viktig gruppe folkehelsearbeidere.

"Med godt forebyggende og helsefremmende arbeid kan flest mulig eldre bo hjemme lengst mulig. Det kan også omfatte eldre med alvorlig helsesvikt. Forebygging og helsefremming er viktig for at eldre skal kunne opprettholde god funksjonsevne og være selvhjulpne. NSF mener at en satsing på helsefremmende innsats i hjemmesykepleien er avgjørende for å unngå sykehusinnleggelser og reinnleggelser.» (NSFs plattform for folkehelse).

\section{Noen konkrete eksempler}

Det handler på mange måter om rett tilbud til rett tid. For å opprettholde fysisk aktivitet, opprettholde muskelmasse og forebygge fall. For å få i seg tilstrekkelig og god mat. For å unngå uheldig kombinasjon av legemidler eller rusbruk. For å forebygge ensomhet og isolasjon. For å fremme helse og trivsel. Områdene er mange og likeledes de gode eksemplene på konkrete grep vi alle kan løfte frem og lære av.

Noen kommuner tilbyr forebyggende hjemmebesøk av trygghetssykepleiere til eldre over 75 år, der formålet er å bidra til å kunne bo hjemme lengst mulig. Det tilbys blant annet gode råd knyttet til sikkerhet i hjemmet og tilbud om aktiviteter og tjenester i kommunen. Friskhet og mestring er hele tiden det som vektlegges.

Tromsø har en egen demenskoordinator hvor både pasienter, pårørende og andre kan ta kontakt uten noen form for henvisning. Tidlige råd styrker mulighetene for å opprettholde mestring lenger.

I Kristiansund har man i sykehjem tatt i bruk en egen ergometersykkel som er koplet til en videoskjerm. På skjermen 
vises reiseruter gjennom ulike strøk i byen. Mens man trener muskulaturen for å forebygge fall, sykler man samtidig gjennom kjente trakter.

I hovedstaden er det etablert et eget «nettverk for eldre og rusbruk i Oslo» (NERO).

Hensikten er å styrke helsen og redusere hjelpebehovet hos eldre gjennom mindre skadelig bruk av psykoaktive stoffer. Ikke gjennom moralisme, men i respektfull dialog i et helsefremmende perspektiv.

Eksemplene illustrerer noen av de sentrale prioriteringene NSF har i folkehelsearbeidet for den aldrende befolkningen: Styrket satsing på helsefremming og forebygging for eldre $\mathrm{i}$ hjemmesykepleien, etablere og styrke oppsøkende forebyggende tjenester for eldre, etablere helsestasjoner for eldre og etablere kvalitetsindikatorer i helsetjenesten for kosthold og fallforebygging for eldre.

Endelig må det også satses videre på avansert geriatrisk sykepleie. Det er den beste garantisten for at tjenestene til eldre utvikler et helsefremmende fokus. Folkehelse i all sykepleie - hele livet.

\section{Kompetansenettverk for folkehelse}

Faggruppene representerer den faglige ekspertisen for NSF på en lang rekke områder. Samtidig ser vi at en rekke temaer berører faget på tvers av de etablerte faggruppene. Folkehelse er et eksempel på dette. På denne bakgrunn er det etablert et eget «kompetansenettverk for folkehelse» med dedikerte

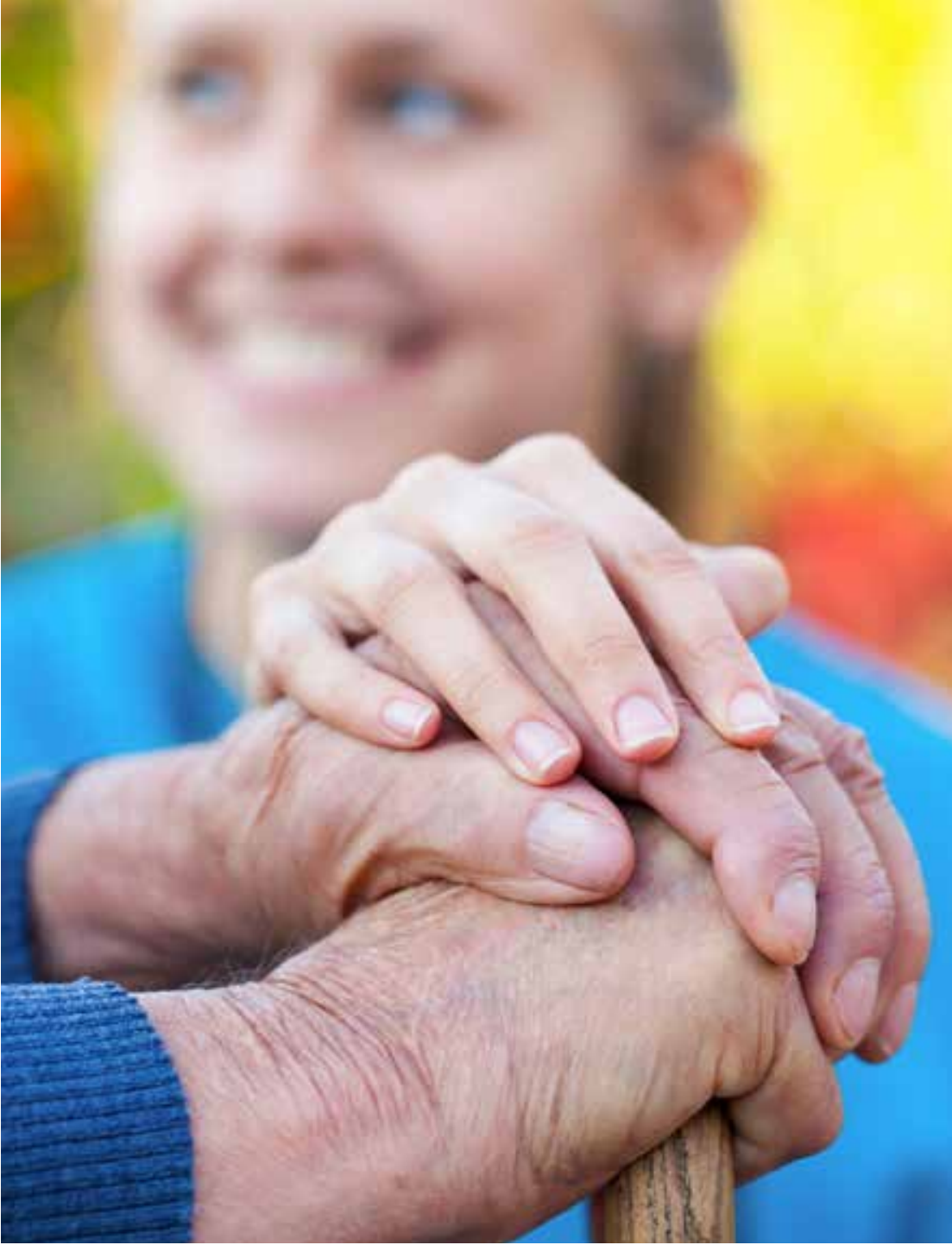

VIKTIG JOBB: Geriatriske sykepleiere giør en stor innsats i det helsefremmende arbeidet. Illustrasjonsfoto: NTB Scanpix Microstock.

medlemmer fra ulike faggrupper. NSF FGD er representert med Åslaug Brende. Hensikten er å bringe inn erfaringer, refleksjoner og eksempler til bruk i NSFs påvirkningsarbeid. Faglig «ferskvare» er verdifullt når vi skal underbygge sykepleieperspektivet i møte med politikere og media.

Kompetansenettverket bidro nylig sammen med Sentralt fagforum til det som vil være NSFs innspill til den kommende meldingen til Stortinget om framtidens primærhelsetjeneste, og også til den kommende nasjonale helse- og sykehusplanen. I disse dager vil nettverket også få bidra i NSFs innspill til ny folkehelsemelding. Et godt samspill med engasjerte og erfarne medlemmer av faggruppene styrker NSF som aktør i folkehelsearbeidet! Det bringer inn aktuelle eksempler og perspektiv som gir troverdighet i argumentasjonen.

Som enkeltpersoner har vi også et ansvar for å påvirke samfunnsutviklingen. Sykepleiere er samfunnsaktører, som det heter i folkehelseplattformen. Sykepleiere i eldreomsorgen har de beste forutsetningene til å være helseopplysere, både på individ-, gruppe- og befolkningsnivå. Hva skal til for at flest mulig skal beholde størst mulig grad av mestring så lenge som mulig? Del kunnskapen og erfaringen! Dere sitter på gullet. 


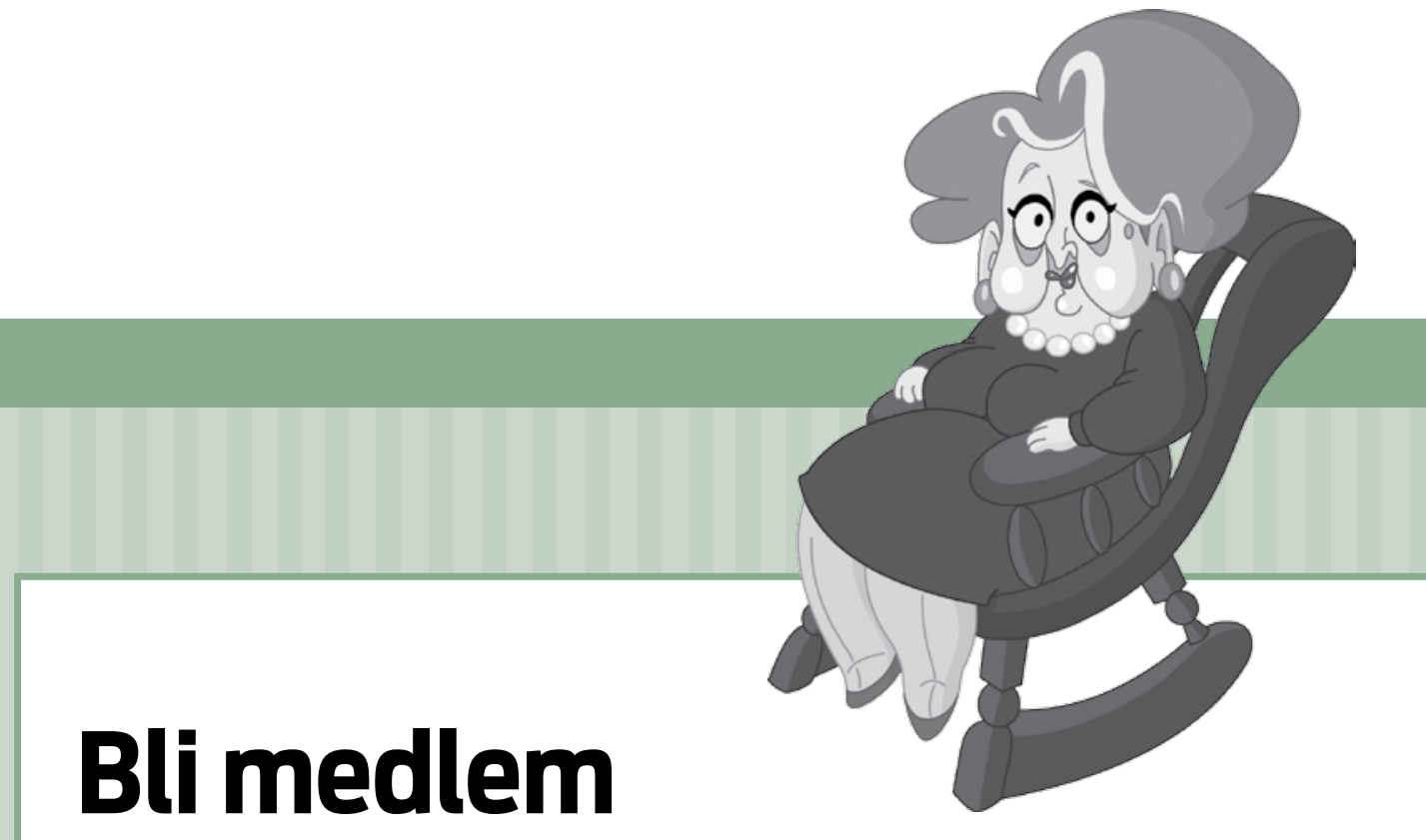

Meld deg inn i NSFs Faggruppe for sykepleiere

i geriatri og demens, du også!

Vi er et slagkraftig fellesskap med mange medlemmer som brenner for fagområdet geriatri og demens. Om du ønsker å bli en del av vårt nettverk, bare fyll ut blanketten nedenfor og send den til vår medlemsansvarlige Gunhild Grythe.

INNMELDINGSBLANKETT

ønsker å bli medlem av NSF FGD

Adresse:

Postnr./sted:

e-postadresse:

Arbeidssted:

Medlemsnr. i NSF:

Kontingent: kr 300,- for 2014.

Pensjonister, medlem som ikke er i aktivt arbeid og sykepleierstudenter betaler 50 prosent av kontingent. Legg innmeldingsblanketten i en konvolutt og send den til:

NSF/FGD, Gunhild Grythe, 2910 Aurdal.

Eller du kan sende en e-post med opplysningene til gunhil-g@online.no

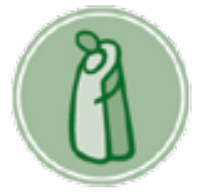

